\title{
Main European unifloral honeys: descriptive sheets ${ }^{1}$
}

\author{
Livia PERSANO ODDOa*, Roberto PIRO ${ }^{\mathrm{b}}$ \\ with the collaboration of: \\ Étienne Bruneau, Christine GuYOT-DECLERCK (Belgium); Tzeko IVANOV \\ (Bulgaria); Jiřina PIŠKULOVÁ (Czech Republic); Christian FlAMINI, Joel LHERITIER, \\ Monique MORLOT (France); Harald RuSSMANN, Werner VON DER OHE, \\ Katharine Von der OHE (Germany); Panagiota GotsIOU, Sophia KARABOURNIOTI, \\ Panagiotis Kefalas, Maria PAsSAloglou-Katrali, Andreas Thrasyvoulou, \\ Angeliki TsigOURI (Greece); Gian Luigi MARCAZZAN, Maria Lucia PIANA, \\ Maria Gioia PIAZZA, Anna Gloria SABATINI (Italy); Jacob KeRKVLIET (Netherlands); \\ Joana GodinHo (Portugal); Antonio BENTABOL, Alberto OrTIZ VALbUENA (Spain), \\ Stefan BOGDANOv, Kaspar RUOFF (Switzerland) \\ a Istituto Sperimentale per la Zoologia Agraria, Sezione di Apicoltura, Roma, Italy \\ b Istituto Zooprofilattico Sperimentale della Lombardia e dell'Emilia Romagna, Brescia, Italy
}

(Received 20 February 2004; revised 11 May 2004; accepted 17 May 2004)

unifloral honey / Europe / physicochemical characteristics / melissopalynology / sensory characteristics / database

\section{INTRODUCTION}

In Europe more than 100 botanical species are known to produce unifloral honey (Persano Oddo et al., 2004). Most of them are produced occasionally or are only of local interest, whereas others are part of the import-export market between different European countries.

In the International Honey Commission of Apimondia (IHC), a working group was constituted in 1998 , with the participation of 28 researchers specialized in honey analysis from 20 different laboratories (11 countries), with the aim of collecting analytical data related to the main European unifloral honeys and of elaborating them to provide the quality criteria for each important honey type.

\section{MATERIALS AND METHODS}

\subsection{Data bank}

The list of members of the IHC participating in the working group is integrally reported in the online version (Appendix5.pdf). They provided the information and the analytical data available in the respective laboratories, related to physicochemical, organoleptic and melissopalynological parameters of a number of authentic unifloral samples (participants were responsible for the authenticity of unifloral samples).

More than 61000 raw data were supplied, related to 6719 honey samples produced in 21 countries of the European geographical area, and analysed for more than 30 physicochemical parameters.

For the characterisation work, 15 honey types were selected, as the most important in terms of abundance of production or commercial relevance in European countries. Among the set of parameters,

\footnotetext{
${ }^{1}$ Research carried out in the frame of the Italian national program of the Ministero delle Politiche Agricole, CE Regulation 1221/97.

* Corresponding author: livia.persano@ apicoltura.org
} 
Table I. List of parameters selected for the description of European unifloral honeys.

\begin{tabular}{|c|c|}
\hline \multirow{3}{*}{ Sensory analysis } & Visual \\
\hline & Olfactory \\
\hline & Taste \\
\hline \multirow{2}{*}{$\begin{array}{l}\text { Melissopalynological } \\
\text { analysis }\end{array}$} & Qualitative \\
\hline & Quantitative \\
\hline \multirow{17}{*}{$\begin{array}{l}\text { Physicochemical } \\
\text { analysis }\end{array}$} & Colour \\
\hline & Electrical conductivity \\
\hline & Specific rotation \\
\hline & Water \\
\hline & Diastase \\
\hline & Invertase \\
\hline & Proline \\
\hline & $\mathrm{pH}$ \\
\hline & Free acidity \\
\hline & Lactones \\
\hline & Total acidity \\
\hline & Fructose \\
\hline & Glucose \\
\hline & Sucrose \\
\hline & Fructose + Glucose $(\mathrm{F}+\mathrm{G})$ \\
\hline & Fructose/Glucose ratio $(\mathrm{F} / \mathrm{G})$ \\
\hline & Glucose/Water ratio (G/W) \\
\hline
\end{tabular}

the most representative and most often used were chosen for describing the European unifloral honeys (Tab. I). Possible extra parameters characteristic for some honey types are quoted in the single descriptive sheets. In Table II the selected honey types with the respective number of samples and analytical data are reported.

Data were transferred in a normalised database (MS Access 97). In several cases (about 3\%) data needed to be converted in terms of units of measurement. More than 54\% of samples reported the year of production and/or analysis: the total range of years is between 1970 and 2002, but more than $90 \%$ of data were produced in the period 1990-2002.

Before the inclusion in the data bank, the data were verified and compared with the international standards, in order to avoid the inclusion of irregular honeys. Figure 1 shows the behaviour of water and HMF content respectively.

After this first check, mean, standard deviation, minimum and maximum values were calculated for each honey type and for each parameter. Then, a comparison between results of the different laboratories was carried out (F-test of data). In Figure 2 an example is presented related to the distribution of electrical conductivity of Robinia honey: data of the
Table II. Number of samples and analytical data collected for each of the 15 honey types chosen.

\begin{tabular}{|l|c|c|}
\hline HONEY TYPES & $\begin{array}{c}\text { No. of } \\
\text { samples }\end{array}$ & $\begin{array}{c}\text { No. of ana- } \\
\text { ytical data }\end{array}$ \\
\hline $\begin{array}{l}\text { Brassica napus } \text { L. and “turnip } \\
\text { rape” }\end{array}$ & 715 & 5939 \\
\hline Calluna vulgaris (L.) Hull & 219 & 1468 \\
\hline Castanea sativa Miller & 495 & 4834 \\
\hline Citrus spp. & 299 & 2555 \\
\hline Eucalyptus spp. & 208 & 1692 \\
\hline Helianthus annuus L. & 358 & 3312 \\
\hline Lavandula spp. & 261 & 2041 \\
\hline Rhododendron spp. & 139 & 1495 \\
\hline Robinia pseudacacia L. & 715 & 5833 \\
\hline Rosmarinus officinalis L. & 515 & 4017 \\
\hline Taraxacum officinale Weber & 114 & 1131 \\
\hline Thymus spp. & 308 & 2313 \\
\hline Tilia spp. & 261 & 2411 \\
\hline Honeydew honey & 721 & 5530 \\
\hline $\begin{array}{l}\text { Honeydew honey from } \\
\text { Metcalfa pruinosa } \text { (Say) }\end{array}$ & 153 & 1610 \\
\hline Total & 5481 & 46181 \\
\hline
\end{tabular}

total sampling are compared with those from different laboratories. Generally, a very good agreement was found among laboratories. When results of a single laboratory were not in agreement with the others, they were discussed in the working group, to identify the possible source of the difference (analytical method or error): if the differences could not be explained, they are reported or commented on in the respective descriptive sheets.

Finally, in order to show up possible errors, other general controls were performed, like the general behaviour of the parameters, the sum of main components (no more than $100 \%$ ), etc.

After the above-mentioned selections the total number of used data was 46181 related to 5481 honey samples (respectively $76 \%$ and $81 \%$ of original data received).

For each single parameter the average values, standard deviation and confidence intervals at $95 \%$ were calculated for each honey type.

\subsection{Analytical methods}

The physico chemical methods, used for the honey characterisation are those of the IHC (Bogdanov et al., 1997). The values of the electrical conductivity 

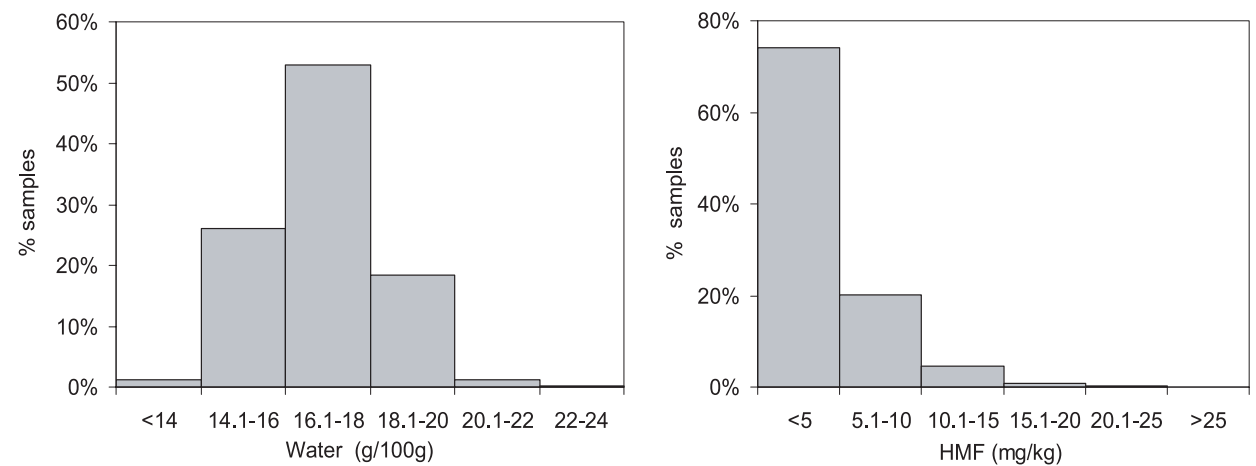

Figure 1. Water and HMF content in the IHC honey samples.

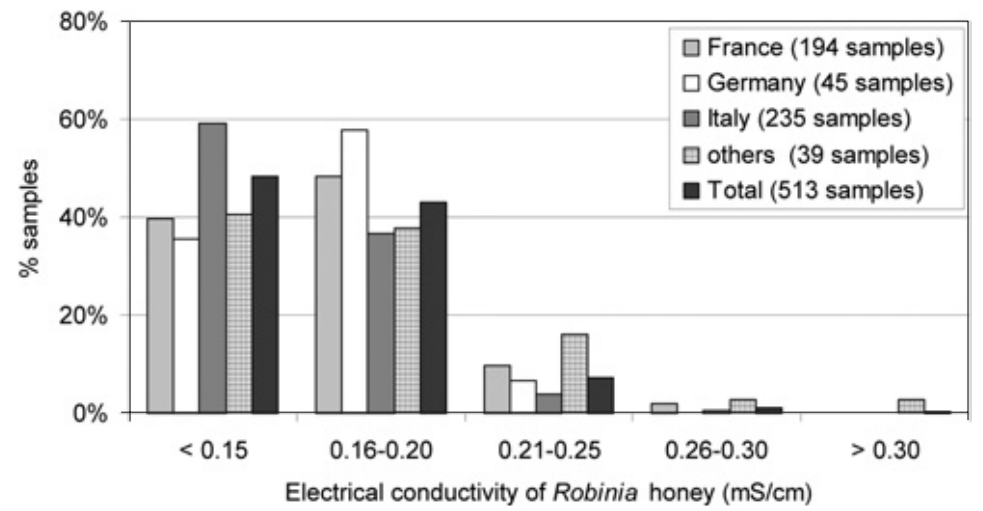

Figure 2. Distribution of electrical conductivity of Robinia honey. The total sampling is compared with the data from different laboratories.

and specific rotation are expressed on honey dry matter, the other ones on honey itself.

The pollen analysis was carried out according to the IHC protocol (von der Ohe et al., 2004). The sensory descriptions were based on the harmonized sensory terminology (Piana et al., 2004).

\section{RESULTS}

For each of 15 unifloral types studied, a descriptive sheet was compiled, where the following items are reported:

- a text with general information on the honey type and notes on its relevant characteristics;

- pollen photograph (courtesy of Katharina von der Ohe);

- a table with sensory characteristics (according to Piana et al., 2004);

- a table with melissopalynological characteristics;
- a table with physicochemical characteristics. For each parameter the number of samples, the average values, standard deviation and confidence intervals at $95 \%$ are given; if the confidence limit was greater than the real minimum or maximum value, the real value was given. On the right size of the table, the number of laboratories that provided the data and the total number of data per country are also reported ( ${ }^{\text {lab }}{ }_{\text {Country }}$ data $)$, as an indication of the weight of each country on the final average values.

Sometimes, the botanical species that give rise to the unifloral honeys described in this work are not the same in all the countries where the honeys are produced: in other words, the same generic name can be used in different countries (or even in the same country), for honeys coming from one or more different species, hybrids, varieties or cultivars belonging to 
the same botanical group. These cases are discussed in the respective sheets.

\section{DISCUSSION}

\subsection{Diagnosis of unifloral honeys}

In the routine work, when the analyst has to verify the botanical denomination of a single honey sample, all three complementary approaches have to be taken into account, melissopalynological, sensory and physicochemical. Melissopalynological analysis does not classify unequivocally unifloral honeys, and sensory evaluation may suffer from a certain subjectivity. On the other hand, the discriminating power of physicochemical parameters is to a certain extent affected by the honey variability. Therefore, the whole analytical picture of the sample has to be considered and interpreted in order to establish if it corresponds to the 'reference model' for that botanical origin (Persano Oddo and Bogdanov, 2004). First, the sensory correspondence has to be evaluated; that must comply with the consumer expectation; then the melissopalynological characteristics have to be consistent with the declared botanical origin, and finally, the physicochemical values have to fall into the ranges specific for that honey type, with particular attention to the more characterising parameters.

According to previous researches on statistical analysis of unifloral analytical data (Mateo and Bosch-Reig, 1998; Piro et al., 2002), the following parameters were found to have the greatest discriminatory power: colour, electrical conductivity, specific rotation, diastase, acidity, fructose and glucose content. Their values (average and standard deviation) for the European unifloral honeys are reported in Table III. To provide more information, in the table also other honey types are included, for which some data were present in the data base, but that were not consistent enough for including them in the descriptive sheets. In the table the highlighted cells indicate, for each parameter, the honey types presenting the highest and the lowest values: indeed, it was demonstrated that, for each honey type, parameters showing very high or very low values have a greater classification power than the ones with medium values (Persano et al., 2000). The variability of the dif- ferent parameters in the 15 unifloral honey types is shown in Figure 3.

\subsection{A practical tool for the control of unifloral honeys}

On the basis of the physicochemical data, a practical tool was elaborated for the routine control of the botanical denominations. The aim was to devise a type of graphic able to represent, for each unifloral type, a characteristic physicochemical profile, containing all the most discriminating parameters: colour, electrical conductivity, specific rotation, acidity, diastase and sugars (fructose, glucose, fructose+glucose, fructose/glucose ratio and glucose/water ratio).

All these parameters have different measurement units and numeric values. In order to report them on the same graphic (one for each honey type), the values of each parameter (average values, standard deviation and confidence intervals) are transformed, so that they represent percentages of the total range found for that parameter on the whole data set (max value - min value), as follows:

$$
v_{a l} \%=\frac{v a l_{a}-v a l_{\min }}{\text { total range }} \cdot 100
$$

where:

$v_{a l} \%$ is the transformed value

$v a l_{a}$ is the original experimental value

$v a l_{\text {min }}$ is the experimental minimum value found for that parameter on the whole data set

total range is the experimental range found for that parameter on the whole data set (maximum value - minimum value).

Example. The average value of electrical conductivity in Robinia honey is $0.16 \mathrm{mS} / \mathrm{cm}$. For electrical conductivity the minimum value found on the whole data set is $0.08 \mathrm{mS} / \mathrm{cm}$ and the maximum is 2.17 (total range $=2.09$ ). The transformed value of Robinia average conductivity, will be:

$$
\frac{0.16-0.08}{2.09} \cdot 100=3.8 \% \text {. }
$$

In this way it was possible to put on the same graphic all the discriminating parameters related to each honey type, obtaining physicochemical profiles giving a synoptic view of the honey physicochemical behaviour (Fig. 4). 
Table III - Characterising parameters of the European unifloral honeys (the whole data set is considered, including honeys not described in the sheets). The highlighted cells indicate, for each honey type, the more characterising parameters (light grey $=$ low values; dark grey $=$ high values).

\begin{tabular}{|c|c|c|c|c|c|c|c|c|c|c|}
\hline $\mathrm{HON}$ & 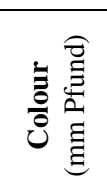 & 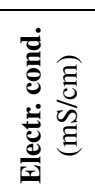 & 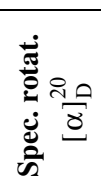 & 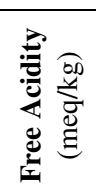 & 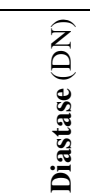 & 总 & 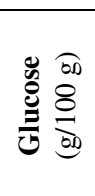 & 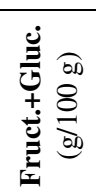 & 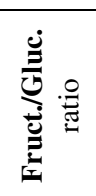 & 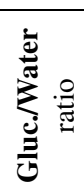 \\
\hline Arbu & $\begin{array}{c}70.1 \pm \\
10.0\end{array}$ & $\begin{array}{c}0.74 \pm \\
0.10\end{array}$ & $\begin{array}{l}-13.1 \pm \\
1.9\end{array}$ & $\begin{array}{c}35.1 \pm \\
8.1\end{array}$ & $\begin{array}{c}4.6 \pm \\
2.8\end{array}$ & $\begin{array}{c}37.6 \pm \\
1.5\end{array}$ & $\begin{array}{c}32.7 \pm \\
1.2\end{array}$ & $\begin{array}{c}70.3 \pm \\
2.3\end{array}$ & $\begin{array}{l}1.15 \pm \\
0.05\end{array}$ & $\begin{array}{c}1.76 \pm \\
0.18\end{array}$ \\
\hline Brassica & $\begin{array}{c}26.2 \pm \\
4.1\end{array}$ & $\begin{array}{c}0.19 \pm \\
0.05\end{array}$ & - & $\begin{array}{c}10.3 \pm \\
2.1\end{array}$ & $\begin{array}{c}26.9 \pm \\
5.8\end{array}$ & $\begin{array}{c}38.3 \pm \\
1.7\end{array}$ & $\begin{array}{c}40.5 \pm \\
2.6\end{array}$ & $\begin{array}{c}78.7 \pm \\
3.5\end{array}$ & $\begin{array}{c}0.95 \pm \\
0.07\end{array}$ & $\begin{array}{c}2.37 \pm \\
0.21\end{array}$ \\
\hline Calluna & $\begin{array}{c}76.9 \pm \\
18.5\end{array}$ & $\begin{array}{c}0.73 \pm \\
0.12\end{array}$ & - & $\begin{array}{c}32.1 \pm \\
5.6\end{array}$ & $\begin{array}{c}23.4 \pm \\
6.3\end{array}$ & $\begin{array}{c}40.8 \pm \\
2.0\end{array}$ & $\begin{array}{c}32.5 \pm \\
1.6\end{array}$ & $\begin{array}{c}73.4 \pm \\
3.1\end{array}$ & $\begin{array}{c}1.26 \pm \\
0.07\end{array}$ & $\begin{array}{c}1.76 \pm \\
0.16\end{array}$ \\
\hline Cast & $\begin{array}{c}87.9 \pm \\
16.0\end{array}$ & $\begin{array}{c}1.38 \pm \\
0.27\end{array}$ & $\begin{array}{l}16.7 \pm \\
3.4\end{array}$ & $\begin{array}{c}13.0 \pm \\
3.5\end{array}$ & $\begin{array}{c}24.3 \pm \\
5.7\end{array}$ & $\begin{array}{c}40.8 \pm \\
2.6\end{array}$ & $\begin{array}{c}27.9 \pm \\
2.5\end{array}$ & $\begin{array}{c}68.7 \pm \\
2.5\end{array}$ & $\begin{array}{c}1.48 \pm \\
0.19\end{array}$ & $\begin{array}{c}1.62 \pm \\
0.13\end{array}$ \\
\hline Citrus & $\begin{array}{c}15.0 \pm \\
6.6\end{array}$ & $\begin{array}{c}0.19 \pm \\
0.06\end{array}$ & $\begin{array}{c}-13.4 \pm \\
2.4\end{array}$ & $\begin{array}{c}14.3 \pm \\
3.2\end{array}$ & $\begin{array}{l}9.6 \pm \\
2.9\end{array}$ & $\begin{array}{c}38.7 \pm \\
2.6\end{array}$ & $\begin{array}{c}31.4 \pm \\
2.1\end{array}$ & $\begin{array}{c}70.1 \pm \\
3.5\end{array}$ & $\begin{array}{c}1.24 \pm \\
0.12\end{array}$ & $\begin{array}{l}1.92 \pm \\
0.15\end{array}$ \\
\hline $\begin{array}{l}\text { Erica arbo- } \\
\text { rea** }\end{array}$ & $\begin{array}{c}99.1 \pm \\
12.9\end{array}$ & $\begin{array}{c}0.70 \pm \\
0.09\end{array}$ & $\begin{array}{c}-13.9 \pm \\
1.6\end{array}$ & $\begin{array}{c}34.7 \pm \\
5.0\end{array}$ & $\begin{array}{l}8.7 \pm \\
3.5\end{array}$ & $\begin{array}{c}38.4 \pm \\
1.3\end{array}$ & $\begin{array}{c}34.7 \pm \\
1.2\end{array}$ & $\begin{array}{c}73.1 \pm \\
1.6\end{array}$ & $\begin{array}{l}1.11 \pm \\
0.06\end{array}$ & $\begin{array}{c}1.89 \pm \\
0.18\end{array}$ \\
\hline Eucalyptus & $\begin{array}{c}54.2 \pm \\
9.4\end{array}$ & $\begin{array}{c}0.48 \pm \\
0.06\end{array}$ & $\begin{array}{c}-13.3 \pm \\
2.3\end{array}$ & $\begin{array}{c}19.4 \pm \\
5.3\end{array}$ & $\begin{array}{c}25.5 \pm \\
4.8\end{array}$ & $\begin{array}{c}39.1 \pm \\
2.2\end{array}$ & $\begin{array}{c}33.0 \pm \\
1.9\end{array}$ & $\begin{array}{c}72.0 \pm \\
3.3\end{array}$ & $\begin{array}{c}1.19 \pm \\
0.09\end{array}$ & $\begin{array}{c}2.14 \pm \\
0.15\end{array}$ \\
\hline Hed. & $\begin{array}{c}18.4 \pm \\
8.3\end{array}$ & $\begin{array}{c}0.20 \pm \\
0.05\end{array}$ & $\begin{array}{c}-10.8 \pm \\
2.7\end{array}$ & $\begin{array}{c}27.2 \pm \\
8.0\end{array}$ & $\begin{array}{c}21.3 \pm \\
5.2\end{array}$ & $\begin{array}{c}39.0 \pm \\
1.4\end{array}$ & $\begin{array}{c}32.1 \pm \\
1.3\end{array}$ & $\begin{array}{c}71.1 \pm \\
1.9\end{array}$ & $\begin{array}{c}1.22 \pm \\
0.07\end{array}$ & $\begin{array}{l}1.90 \pm \\
0.12\end{array}$ \\
\hline Helia & $\begin{array}{c}52.4 * \pm \\
9.0\end{array}$ & $\begin{array}{c}0.34 \pm \\
0.08\end{array}$ & $\begin{array}{c}-17.5 \pm \\
1.9\end{array}$ & $\begin{array}{c}23.1 \pm \\
6.3\end{array}$ & $\begin{array}{c}20.8 \pm \\
5.6\end{array}$ & $\begin{array}{c}39.2 \pm \\
1.6\end{array}$ & $\begin{array}{c}37.4 \pm \\
1.5\end{array}$ & $\begin{array}{c}76.7 \pm \\
2.7\end{array}$ & $\begin{array}{c}1.05 \pm \\
0.04\end{array}$ & $\begin{array}{c}2.10 \pm \\
0.13\end{array}$ \\
\hline$L a$ & $\begin{array}{c}33.3 \pm \\
6.5\end{array}$ & $\begin{array}{c}0.21 \pm \\
0.05\end{array}$ & $\begin{array}{c}-8.3 \pm \\
3.8\end{array}$ & $\begin{array}{c}17.3 \pm \\
4.0\end{array}$ & $\begin{array}{c}14.1 \pm \\
2.4\end{array}$ & $\begin{array}{c}36.0 \pm \\
1.9\end{array}$ & $\begin{array}{c}30.6 \pm \\
1.7\end{array}$ & $\begin{array}{c}66.6 \pm \\
2.9\end{array}$ & $\begin{array}{c}1.18 \pm \\
0.07\end{array}$ & $\begin{array}{c}1.88 \pm \\
0.09\end{array}$ \\
\hline Pho & - & $\begin{array}{c}0.23 \pm \\
0.09\end{array}$ & - & $\begin{array}{c}19.8 \pm \\
7.5\end{array}$ & - & $\begin{array}{c}37.3 \pm \\
2.5\end{array}$ & $\begin{array}{c}34.0 \pm \\
1.9\end{array}$ & $\begin{array}{c}71.3 \pm \\
3.8\end{array}$ & $\begin{array}{c}1.10 \pm \\
0.08\end{array}$ & $\begin{array}{c}2.09 \pm \\
0.15\end{array}$ \\
\hline Rho & $\begin{array}{c}12.4 \pm \\
4.0\end{array}$ & $\begin{array}{c}0.23 \pm \\
0.06\end{array}$ & $\begin{array}{c}-5.8 \pm \\
2.4\end{array}$ & $\begin{array}{c}13.3 \pm \\
3.3\end{array}$ & $\begin{array}{c}12.1 \pm \\
2.3\end{array}$ & $\begin{array}{c}39.1 \pm \\
2.1\end{array}$ & $\begin{array}{c}30.4 \pm \\
2.2\end{array}$ & $\begin{array}{c}69.6 \pm \\
3.4\end{array}$ & $\begin{array}{c}1.29 \pm \\
0.10\end{array}$ & $\begin{array}{c}1.79 \pm \\
0.17\end{array}$ \\
\hline Robin & $\begin{array}{c}12.9 \pm \\
5.6\end{array}$ & $\begin{array}{c}0.16 \pm \\
0.04\end{array}$ & $\begin{array}{c}-16.6 \pm \\
3.1\end{array}$ & $\begin{array}{c}11.2 \pm \\
3.4\end{array}$ & $\begin{array}{c}10.5 \pm \\
5.0\end{array}$ & $\begin{array}{c}42.7 \pm \\
2.3\end{array}$ & $\begin{array}{c}26.5 \pm \\
1.7\end{array}$ & $\begin{array}{c}69.2 \pm \\
3.3\end{array}$ & $\begin{array}{c}1.61 \pm \\
0.11\end{array}$ & $\begin{array}{c}1.57 \pm \\
0.13\end{array}$ \\
\hline Ros & $\begin{array}{c}15.0 \pm \\
5.8\end{array}$ & $\begin{array}{c}0.15 \pm \\
0.04\end{array}$ & $\begin{array}{c}-6.1 \pm \\
2.8\end{array}$ & $\begin{array}{c}11.5 \pm \\
4.7\end{array}$ & $\begin{array}{c}9.7 \pm \\
3.2\end{array}$ & $\begin{array}{c}38.4 \pm \\
1.6\end{array}$ & $\begin{array}{c}33.1 \pm \\
2.2\end{array}$ & $\begin{array}{c}71.5 \pm \\
3.0\end{array}$ & $\begin{array}{c}1.16 \pm \\
0.08\end{array}$ & $\begin{array}{c}2.06 \pm \\
0.15\end{array}$ \\
\hline Tarax & $\begin{array}{c}56.6 * \pm \\
10.4\end{array}$ & $\begin{array}{c}0.51 \pm \\
0.07\end{array}$ & $\begin{array}{c}-10.0 \pm \\
2.1\end{array}$ & $\begin{array}{c}10.9 \pm \\
2.0\end{array}$ & $\begin{array}{c}11.3 \pm \\
2.3\end{array}$ & $\begin{array}{c}37.4 \pm \\
1.8\end{array}$ & $\begin{array}{c}38.0 \pm \\
2.8\end{array}$ & $\begin{array}{c}75.2 \pm \\
3.9\end{array}$ & $\begin{array}{c}0.99 \pm \\
0.07\end{array}$ & $\begin{array}{c}2.33 \pm \\
0.15\end{array}$ \\
\hline Thymus & $\begin{array}{c}53.1 \pm \\
10.8\end{array}$ & $\begin{array}{c}0.40 \pm \\
0.07\end{array}$ & $\begin{array}{c}-20.1 \pm \\
2.1\end{array}$ & $\begin{array}{c}37.2 \pm \\
6.3\end{array}$ & $\begin{array}{c}29.2 \pm \\
7.6\end{array}$ & $\begin{array}{c}42.4 \pm \\
2.4\end{array}$ & $\begin{array}{c}30.3 \pm \\
1.8\end{array}$ & $\begin{array}{c}72.7 \pm \\
2.9\end{array}$ & $\begin{array}{c}1.41 \pm \\
0.12\end{array}$ & $\begin{array}{c}1.90 \pm \\
0.13\end{array}$ \\
\hline Tilia & $\begin{array}{c}33.3 \pm \\
13.1\end{array}$ & $\begin{array}{c}0.62 \pm \\
0.12\end{array}$ & $\begin{array}{c}-12.5 \pm \\
2.8\end{array}$ & $\begin{array}{c}20.8 \pm \\
7.7\end{array}$ & $\begin{array}{c}16.8 \pm \\
3.4\end{array}$ & $\begin{array}{c}37.5 \pm \\
2.9\end{array}$ & $\begin{array}{c}31.9 \pm \\
2.5\end{array}$ & $\begin{array}{c}69.5 \pm \\
4.0\end{array}$ & $\begin{array}{c}1.18 \pm \\
0.12\end{array}$ & $\begin{array}{c}1.93 \pm \\
0.19\end{array}$ \\
\hline Hon & $\begin{array}{c}86.0 \pm \\
16.4\end{array}$ & $\begin{array}{c}1.20 \pm \\
0.22\end{array}$ & $\begin{array}{c}13.9 \pm \\
5.7\end{array}$ & $\begin{array}{c}26.0 \pm \\
5.6\end{array}$ & $\begin{array}{c}22.6 \pm \\
5.6\end{array}$ & $\begin{array}{c}32.5 \pm \\
1.9\end{array}$ & $\begin{array}{c}26.2 \pm \\
2.5\end{array}$ & $\begin{array}{c}58.7 \pm \\
3.8\end{array}$ & $\begin{array}{c}1.25 \pm \\
0.12\end{array}$ & $\begin{array}{c}1.61 \pm \\
0.17\end{array}$ \\
\hline Metcalfa h.dew & $\begin{array}{c}100.8 \pm \\
7.5\end{array}$ & $\begin{array}{c}1.69 \pm \\
0.24\end{array}$ & $\begin{array}{c}17.5 \pm \\
6.5\end{array}$ & $\begin{array}{c}37.2 \pm \\
6.6\end{array}$ & $\begin{array}{c}39.3 \pm \\
7.9\end{array}$ & $\begin{array}{c}31.6 \pm \\
3.2\end{array}$ & $\begin{array}{c}23.9 \pm \\
2.7\end{array}$ & $\begin{array}{c}55.5 \pm \\
4.5\end{array}$ & $\begin{array}{c}1.34 \pm \\
0.18\end{array}$ & $\begin{array}{c}1.51 \pm \\
0.18\end{array}$ \\
\hline
\end{tabular}

* Colour of Helianthus and Taraxacum honeys presents a typical yellow hue.

** Honey types not described in the sheets. 

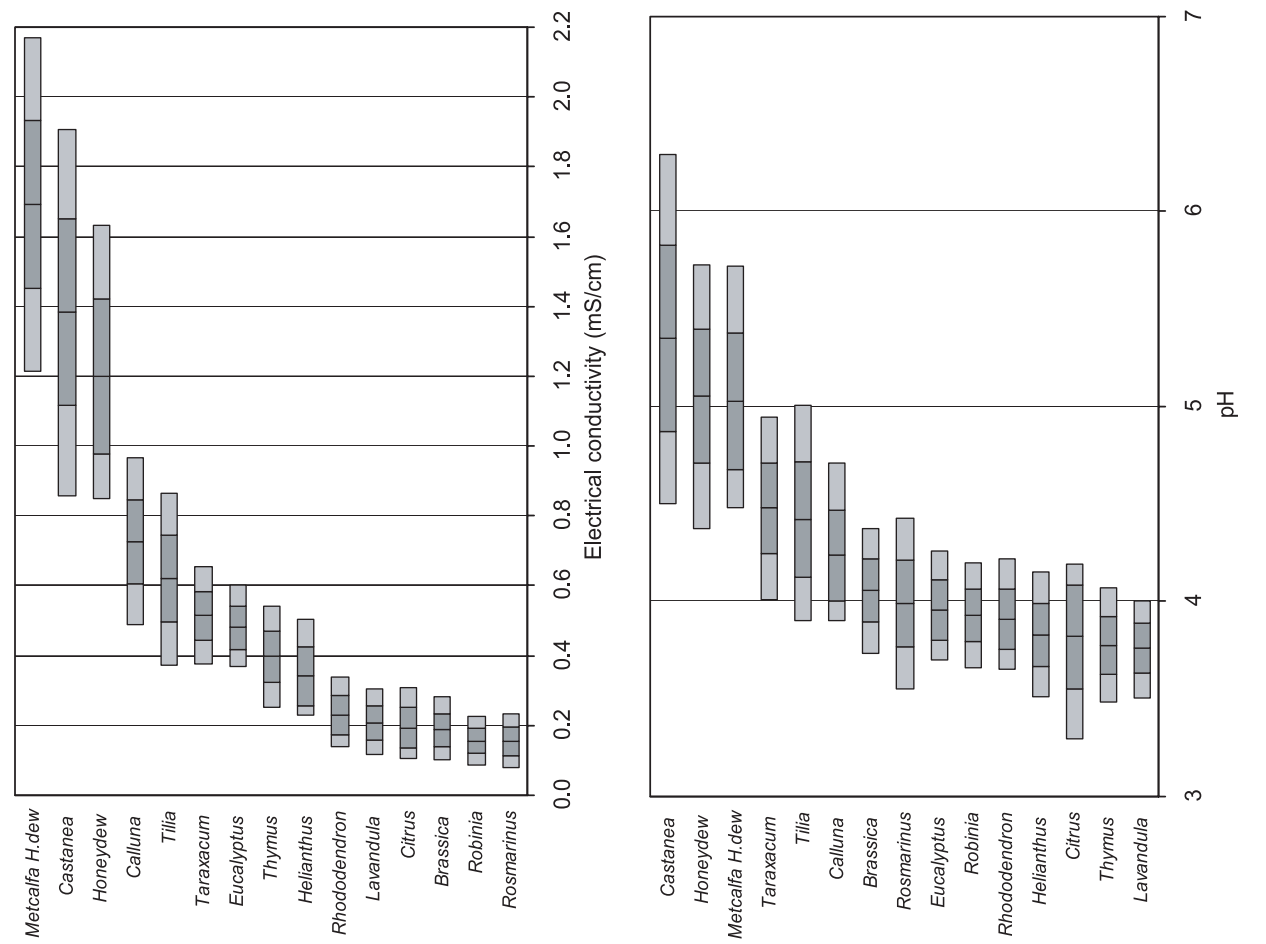

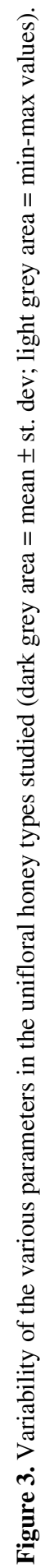
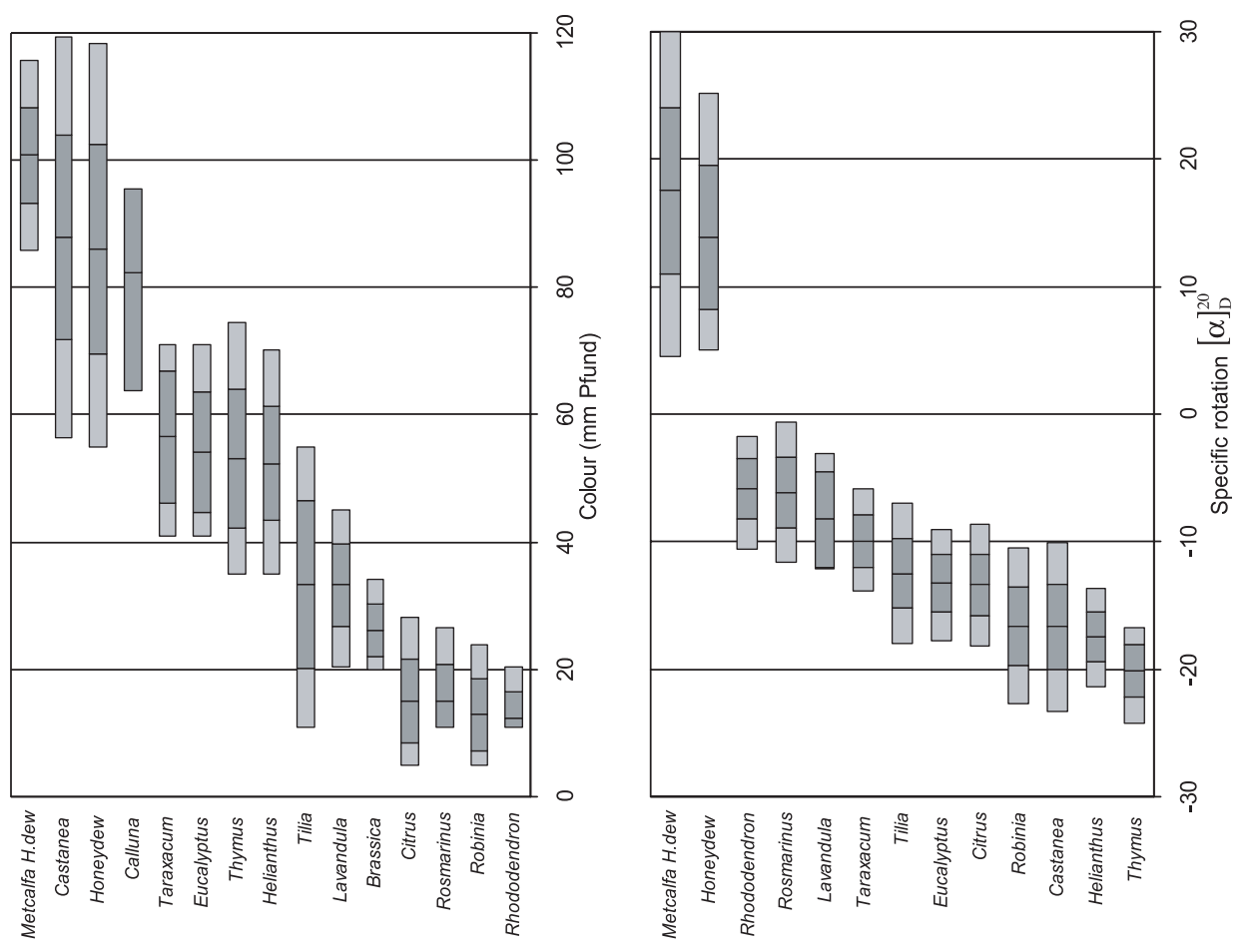

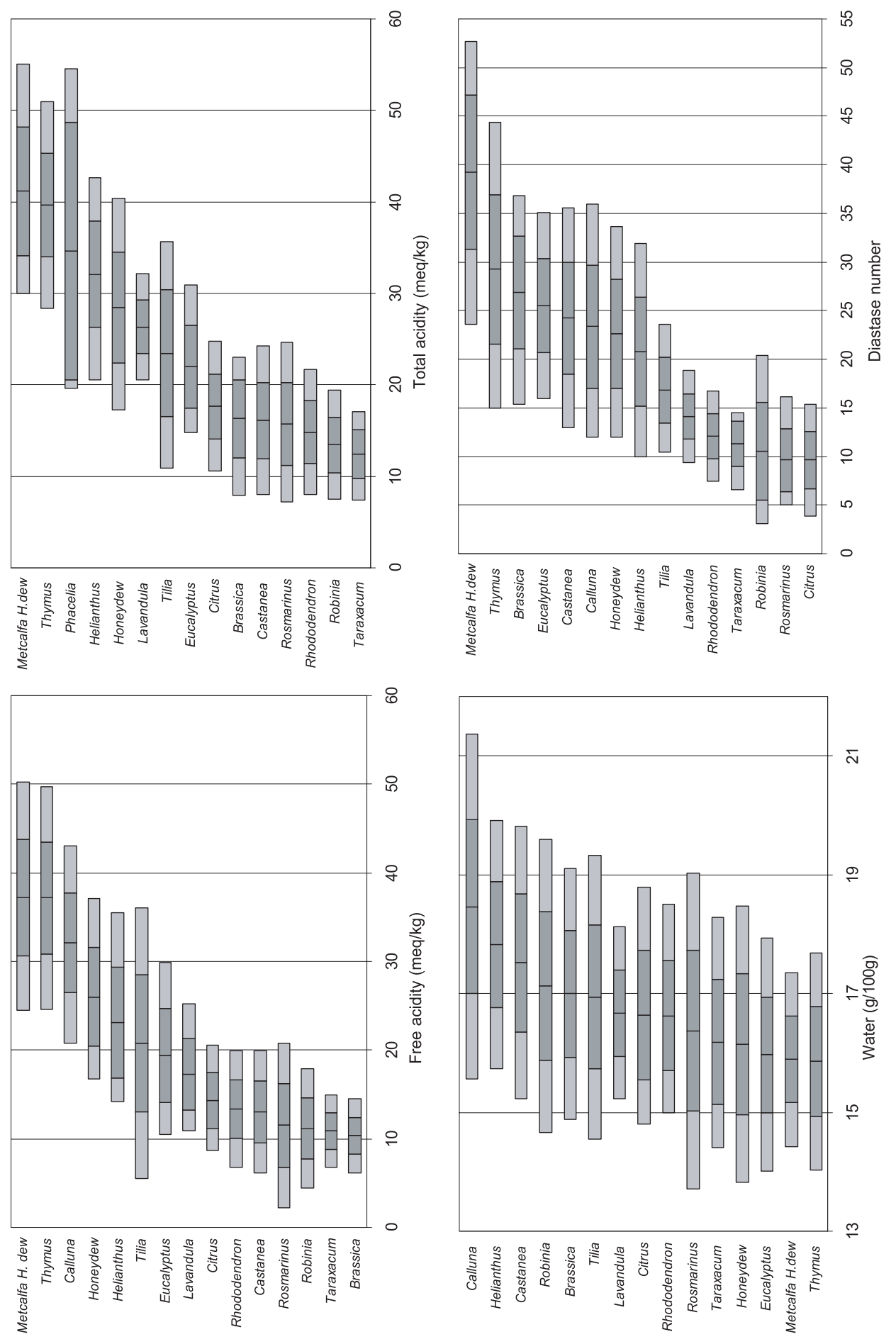

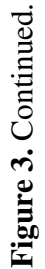



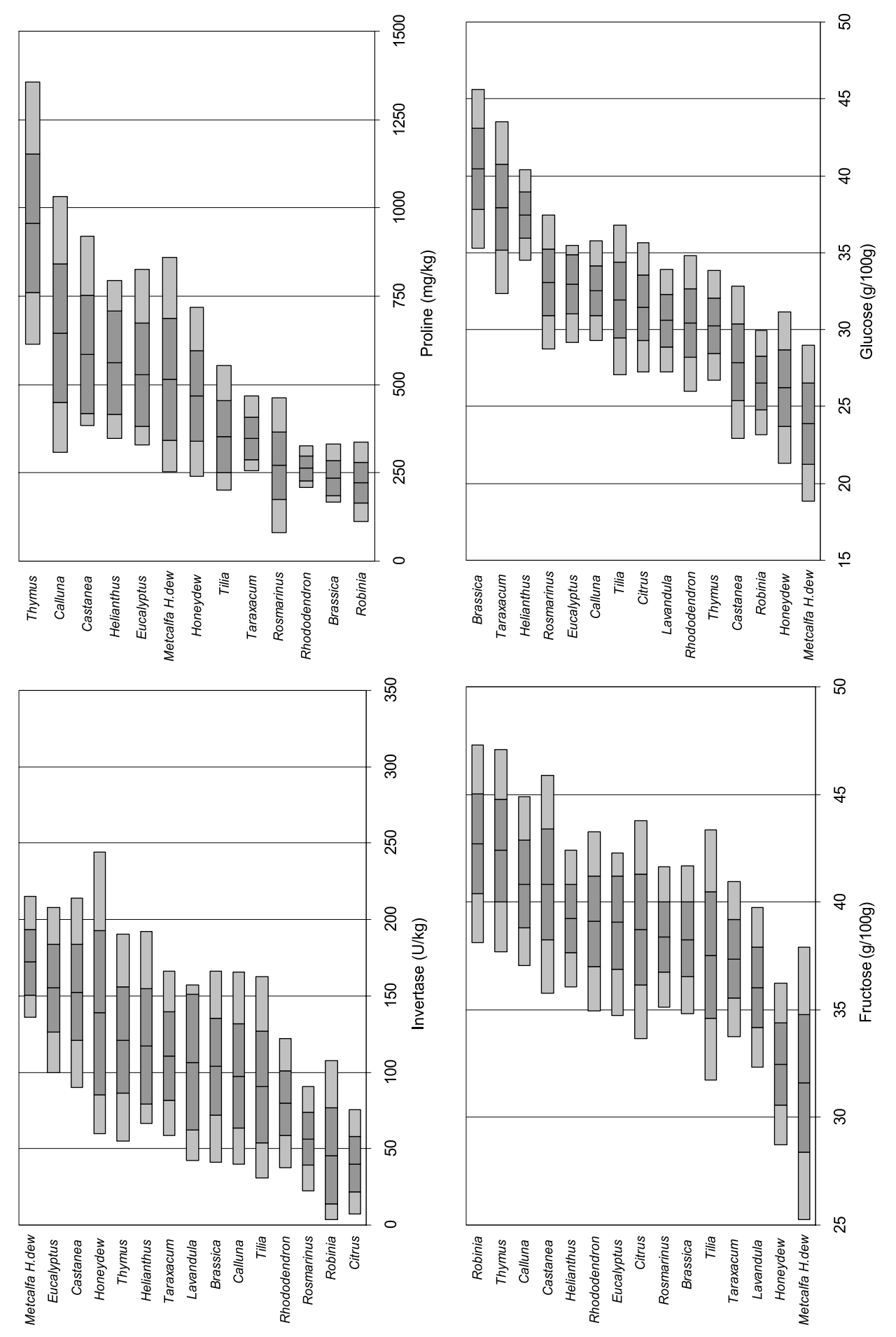

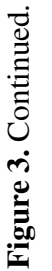



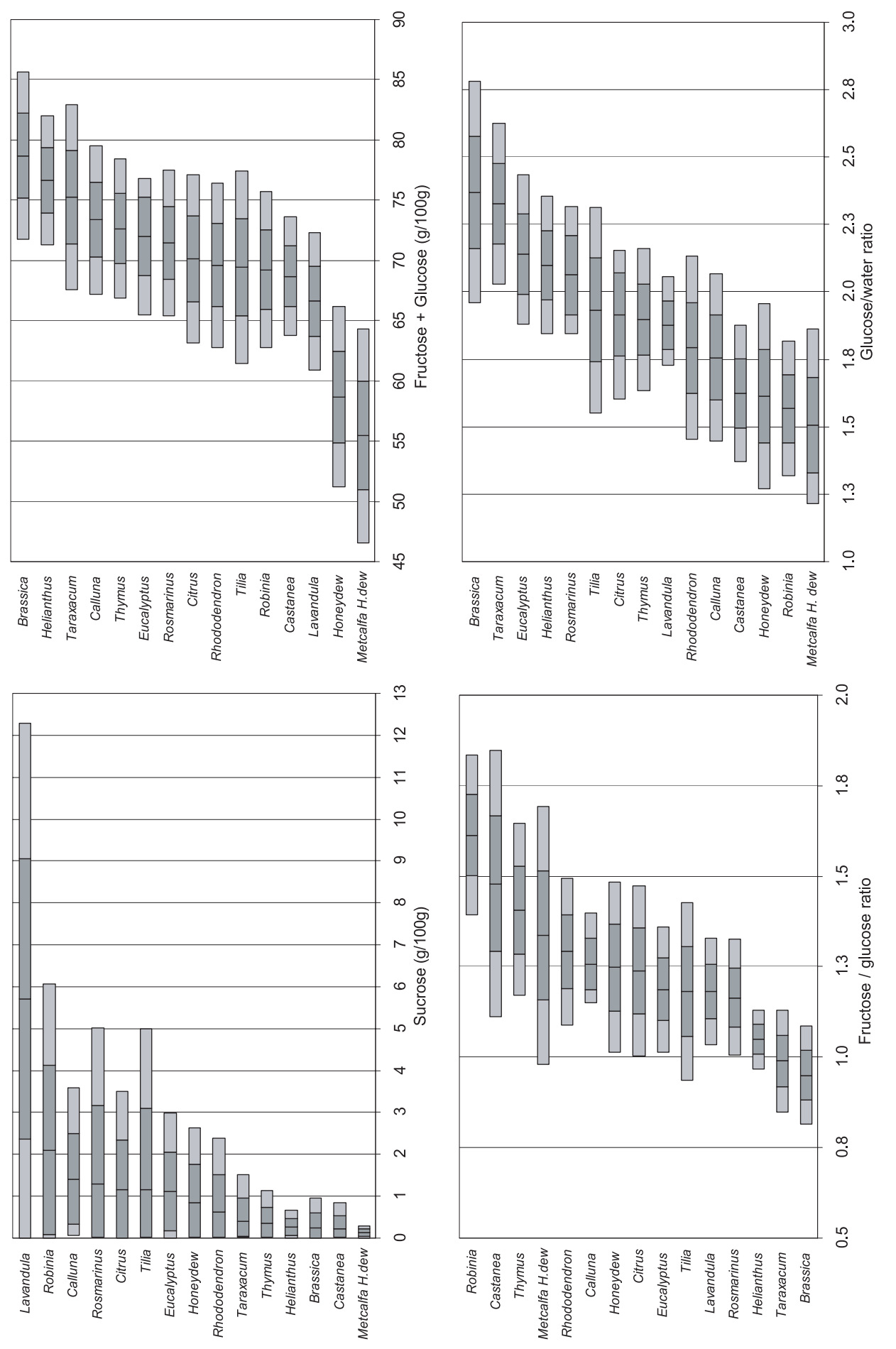

苞 

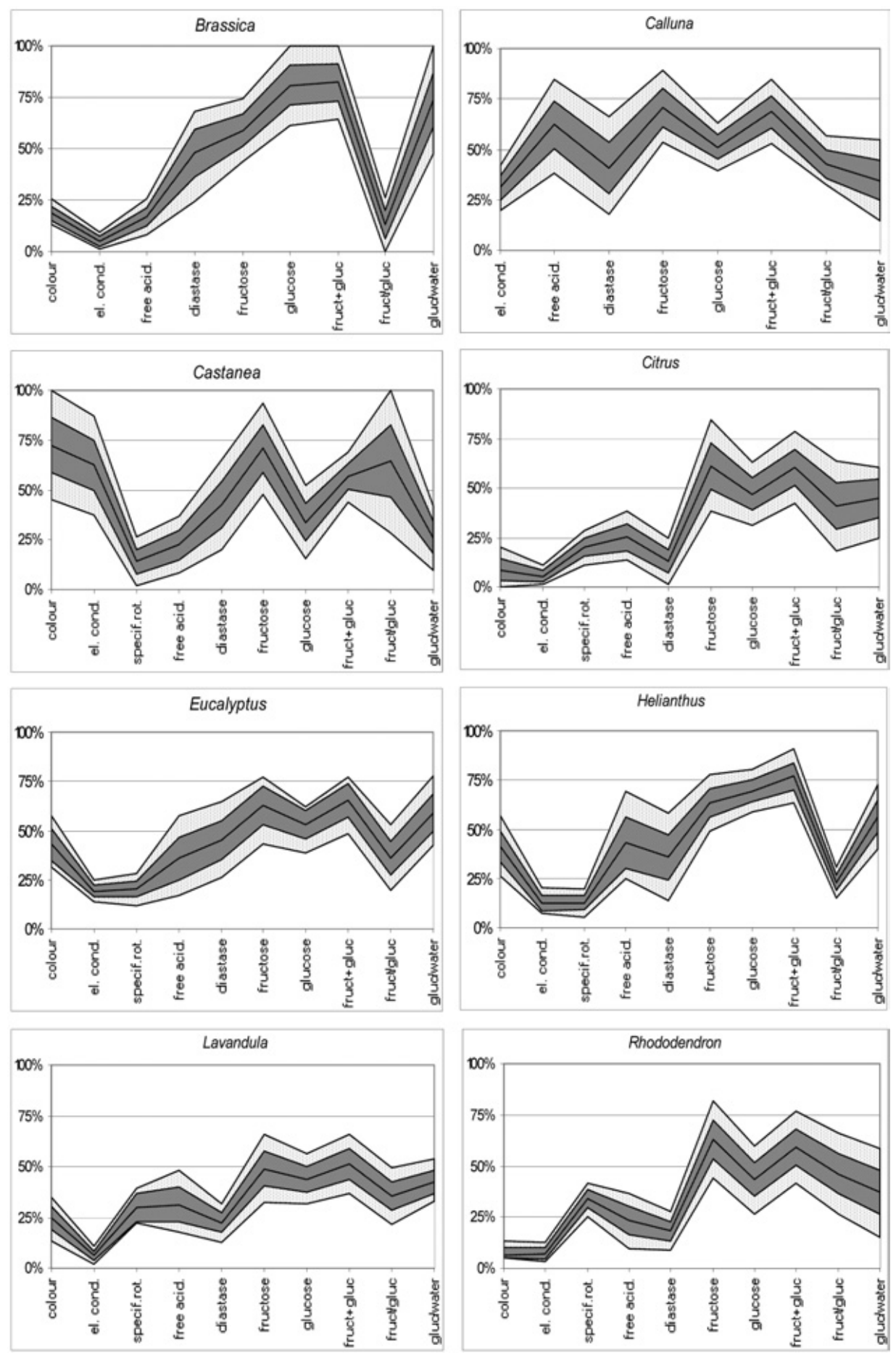

Figure 4. Physicochemical profiles of the main European unifloral honeys. (Values of each parameter are transformed as percentage of the experimental range found for that parameter on the whole data set.) 

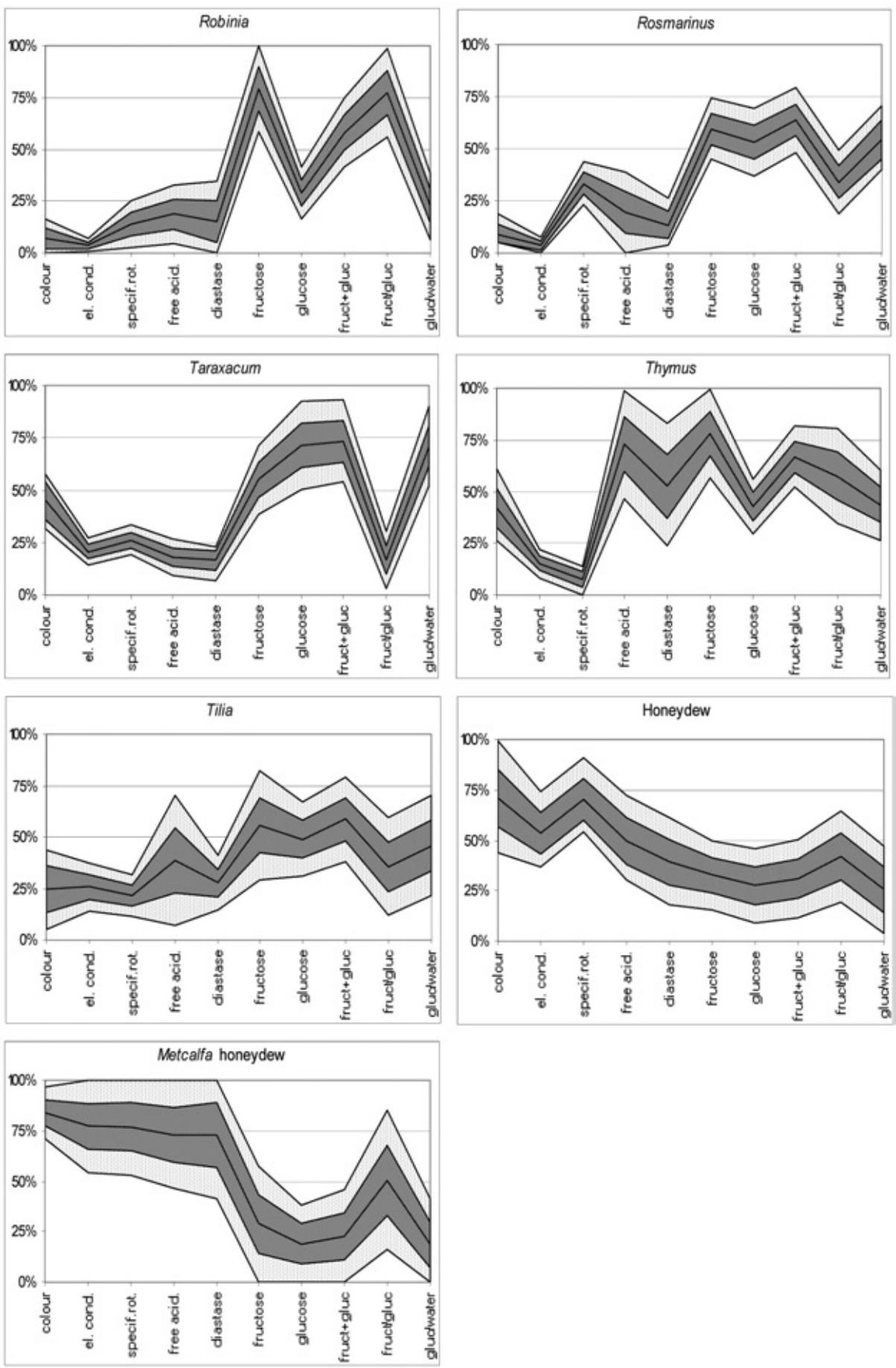

Figure 4. Continued. 
Table IV. Minimum values $\left(\mathrm{Val}_{\min }\right)$ and ranges $\left(\mathrm{Val}_{\max }-\mathrm{Val}_{\min }\right)$ of the main physicochemical parameters.

\begin{tabular}{|l|c|c|}
\hline Parameter & $\begin{array}{c}\text { Minimum } \\
\text { value }\end{array}$ & $\begin{array}{c}\text { Total range } \\
\left(\mathrm{Val}_{\text {max }}-\mathrm{Val}_{\text {min }}\right)\end{array}$ \\
\hline colour $(\mathrm{mm}$ Pfund $)$ & 5.0 & 114.4 \\
\hline $\begin{array}{l}\text { electrical conductivity } \\
(\mathrm{mS} / \mathrm{cm})\end{array}$ & 0.08 & 2.09 \\
\hline specific rotation $[\alpha]_{D}^{20}$ & -24.2 & 54.2 \\
\hline free acidity $(\mathrm{meq} / \mathrm{kg})$ & 2.3 & 49.1 \\
\hline diastase $(\mathrm{DN})$ & 0 & 52.7 \\
\hline fructose $(\mathrm{g} / 100 \mathrm{~g})$ & 25.3 & 22.0 \\
\hline glucose $(\mathrm{g} / 100 \mathrm{~g})$ & 18.8 & 26.8 \\
\hline F+G $(\mathrm{g} / 100 \mathrm{~g})$ & 46.6 & 39.1 \\
\hline F/G ratio & 0.81 & 1.03 \\
\hline G/W ratio & 1.22 & 1.56 \\
\hline
\end{tabular}

To verify the botanical denomination of unknown samples, the global correspondence to the characteristic profile can be evaluated: after analysing the main parameters, the respective "transformed values" are calculated, according to the above formula (for each parameter $\mathrm{val}_{\text {min }}$ and total range values are reported in Tab. IV). The resulting profile is compared to the characteristic profile of that honey type. If the profile mostly falls into the standard deviation range (dark area) the sample is perfectly corresponding to the type; if it falls into the light area it can be considered acceptable; if it is out of the light area, it does not correspond to the type.

The excel file for applying this method is available in the online version (Appendix6.xls).

\subsection{Compliance to norms}

With respect to the composition and quality standards, the values of almost all the 6,719 honey samples analysed by the 20 participants laboratories perfectly comply with the limits established by the new European Directive concerning honey (European Commission, 2002). In Table $\mathrm{V}$ the values found for the Directive parameters in all the 6,719 IHC honey samples are reported and compared with the prescribed limits. For some honey types, particular values were found that should be included among the Directive exceptions. They are highlighted in the table.

\section{CONCLUSIONS}

From the coordinated work carried out by the IHC, an extensive databank was obtained, from which it was possible to outline a fairly complete picture of the main unifloral honey types produced in European countries. In most cases, data from different laboratories were in very good agreement. They are also fairly consistent with those available in the literature (Piazza and Persano Oddo, 2004), some differences mostly depending on the use of different analytical methods.

The descriptive sheets of the main European unifloral honeys give, for the various parameters, ranges of values that include $95 \%$ of the analysed samples. Therefore they reasonably represent a basic criterion of acceptability for the market and a useful reference for the evaluation of botanical denominations. They may assist the control authorities in the different European countries, and stimulate the production and trade of these valuable honey varieties.

\section{REFERENCES}

Bogdanov S., Lüllmann C., Martin P., von der Ohe W., Russmann H., Vorwohl G., Persano Oddo L., Sabatini A.G., Marcazzan G.L., Piro R., Flamini C., Morlot M., Lheritier J., Borneck R., Marioleas P., Tsigouri A., Kerkvliet J., Ortiz A., Ivanov T., D'Arcy B., Mossel B., Vit P. (1999) Honey quality, methods of analysis and international regulatory standards, review of the work of the International Honey Commission, Mitt. Lebensm. Hyg. 90, 108-125.

Bogdanov S., Martin P., Lüllmann C. (1997) Harmonised methods of the European Honey Commission, Apidologie extra issue, 1-59, available online at: http://www.apis.admin.ch/ host/doc/pdfhoney/IHCmethods_e.pdf (accessed on 16 August 2004).

European Commission (2002) Council Directive 2001/110/CE concerning honey, Off. J. Eur. Communities Jan 12th 2002, L10/47-52.

Ferreres F., Garcia Viguera C., Tomas-Lorente F., Tomas Barberan F.A. (1993) Hesperetin: A marker of the floral origin of citrus honey, J. Sci. Food Agric. 61, 121-123. 
Table V. Quality parameters fixed by the new European Directive concerning honey (2001/110/CE). The limits prescribed by the directive are compared with the corresponding experimental values of the samples analysed in the IHC work (the whole data set is considered, including honeys not described in the sheets). Honey types not complying with Directive limits are highlighted, and the extreme values are reported.

\begin{tabular}{|c|c|c|c|c|c|}
\hline \multirow{2}{*}{$\begin{array}{l}\text { Parameter } \\
\mathbf{H}_{\mathbf{2}} \mathbf{O}(\mathrm{g} / 100 \mathrm{~g})\end{array}$} & \multicolumn{2}{|c|}{ EU Directive limits } & \multicolumn{2}{|c|}{$\begin{array}{l}\text { Experimental values } \\
\text { from IHC databank }\end{array}$} & $\begin{array}{l}\text { Total No } \\
\text { of data }\end{array}$ \\
\hline & \multicolumn{2}{|r|}{$<20$} & \multicolumn{2}{|r|}{$<20$} & 3411 \\
\hline Exceptions & Calluna: & $<23$ & Calluna & $\max =21.4$ & 200 \\
\hline \multicolumn{3}{|c|}{ Other honey types that can exceed $20 \mathrm{~g} / 100 \mathrm{~g}$ limit } & Arbutus & $\max =21.0$ & 73 \\
\hline $\begin{array}{l}\text { Fructose+Glucose } \\
(\mathrm{g} / 100 \mathrm{~g})\end{array}$ & \multicolumn{2}{|r|}{$>60$} & & $>60$ & 2342 \\
\hline Exceptions & Honeydew & $>45$ & Honeydews & $>45$ & 474 \\
\hline Sucrose $(\mathrm{g} / 100 \mathrm{~g})$ & \multicolumn{2}{|r|}{$<5$} & & $<5$ & 1305 \\
\hline Exceptions & \begin{tabular}{|l} 
Robinia \\
Hedysarum \\
Eucalyptus \\
Citrus \\
Medicago, Bank \\
Lavandula \\
Borago
\end{tabular} & $\begin{aligned} & <10 \\
& <10 \\
& <10 \\
& <10 \\
\text { rryphia } & <10 \\
& <15 \\
& <15\end{aligned}$ & $\begin{array}{l}\text { Robinia } \\
\text { Hedysarum } \\
\text { Eucalyptus } \\
\text { Citrus } \\
- \\
\text { Lavandula } \\
-\end{array}$ & $\begin{array}{l}\max =10.4 \\
\max =8.3 \\
\max =4.2 \\
\max =6.4 \\
\max =15.2\end{array}$ & $\begin{array}{c}458 \\
35 \\
81 \\
110 \\
- \\
218 \\
-\end{array}$ \\
\hline \multicolumn{3}{|c|}{ Other honey types that can exceed $5 \mathrm{~g} / 100 \mathrm{~g}$ limit } & $\begin{array}{l}\text { Tilia } \\
\text { Rosmarinus } \\
\text { Phacelia }\end{array}$ & $\begin{array}{l}\max =10.0 \\
\max =6.6 \\
\max =8.8\end{array}$ & $\begin{array}{c}131 \\
74 \\
26\end{array}$ \\
\hline \multirow{2}{*}{$\begin{array}{l}\text { Electrical conductivity } \\
\left(\mathrm{mS} \cdot \mathrm{cm}^{-1}\right)\end{array}$} & \multicolumn{2}{|c|}{$<0.8$} & & $<0.8$ & 3123 \\
\hline & \multicolumn{2}{|c|}{ Castanea, Honeydew $>0.8$} & & $>0.8$ & 1158 \\
\hline Exceptions & \multicolumn{2}{|c|}{$\begin{array}{l}\text { Arbutus } \\
\text { Erica } \\
\text { Eucalyptus } \\
\text { Tilia } \\
\text { Calluna } \\
\text { Leptospermum, Melaleuca }\end{array}$} & $\begin{array}{l}\text { Arbutus } \\
\text { Erica } \\
\text { Eucalyptus } \\
\text { Tilia } \\
\text { Calluna } \\
-\end{array}$ & $\begin{array}{l}0.5-0.9 \\
0.6-0.9 \\
0.4-0.6 \\
0.3-0.9 \\
0.4-1.0\end{array}$ & $\begin{array}{c}63 \\
34 \\
163 \\
202 \\
189 \\
-\end{array}$ \\
\hline Free acidity $(\mathrm{meq} / \mathrm{kg})$ & \multicolumn{2}{|r|}{$<50$} & & $<50$ & 2517 \\
\hline \multicolumn{3}{|c|}{ Honey types that can exceed $50 \mathrm{meq} / \mathrm{kg}$ limit } & Metcalfa $\mathrm{Hd}$ & $\max =58.1$ & 116 \\
\hline HMF $(\mathrm{mg} / \mathrm{kg})$ & \multicolumn{2}{|r|}{$<40$} & & $0.1-22.8$ & 1769 \\
\hline Exceptions & tropical honeys & $<80$ & \multicolumn{2}{|l|}{-} & - \\
\hline Diastase (Schade units) & & $>8$ & & $>8$ & 1634 \\
\hline Exceptions & \multicolumn{2}{|c|}{ honeys with low enzyme content: $>3$} & $\begin{array}{l}\text { Citrus } \\
\text { Robinia } \\
\text { Rosmarinus } \\
\text { Taraxacum } \\
\text { Erica }\end{array}$ & $\begin{array}{l}\min =3.9 \\
\min =3.1 \\
\min =5.0 \\
\min =5.2 \\
\min =3.7\end{array}$ & $\begin{array}{c}191 \\
283 \\
59 \\
26 \\
25\end{array}$ \\
\hline \multicolumn{3}{|c|}{ Honey types that can go under the limit of 3 Schade units } & Arbutus & $0-9.7$ & 50 \\
\hline
\end{tabular}


Fiori J., Serra G., Sabatini A.G., Zucchi P., Barbattini R., Gazziola F. (2000) Analisi con HPLC di destrine in mieli di melata di Metcalfa pruinosa (Say), Ind. Aliment. 39, 463-466.

Louveaux J. (1967) Essai de caractérisation des miels de callune (Calluna vulgaris Salisb.), Ann. Abeille 9, 351-358.

Louveaux J. (1970) Annexes microphotographiques aux méthodes officielles d'analyse. Tome III, Atlas photographique d'analyse pollinique des miels, Service de la répression des fraudes et du contrôle de la qualité, Paris.

Louveaux J., Maurizio A., Vorwohl G. (1978) Methods of melissopalynology, Bee World 59, 139-157.

Mateo R., Bosch-Reig F. (1998) Classification of Spanish unifloral honeys by discriminant analysis of electrical conductivity, colour, water content, sugars and pH, J. Agric. Food Chem. 46, 393-400.

Persano Oddo L., Bogdanov S. (2004) Determination of honey botanical origin: problems and issues Apidologie 35 (Suppl. 1), S2-S3.

Persano Oddo L., Sabatini A.G., Accorti M., Colombo R., Marcazzan G.L., Piana M.L., Piazza M.G., Pulcini P. (2000) I mieli uniflorali italiani. Nuove schede di caratterizzazione, Ministero delle Politiche Agricole e Forestali - Istituto Sperimentale Zoologia Agraria, Roma.

Persano Oddo L., Piana L., Bogdanov S., Bentabol A., Gotsiou P., Kerkvliet J., Martin P., Morlot M., Ortiz Valbuena A., Ruoff K., von der Ohe K. (2004) Botanical species giving unifloral honey in Europe, Apidologie 35 (Suppl. 1), S81-S93.

Piana M.L., Persano Oddo L., Bentabol A., Bruneau E., Bogdanov S., Guyot-Declerck C. (2004) Sensory analysis applied to honey: state of the art, Apidologie 35 (Suppl. 1), S26-S37.
Piazza M.G., Persano Oddo L. (2004) Bibliographical review of the main European unifloral honeys, Apidologie 35 (Suppl. 1), S94-S111.

Piro R., Guidetti G., Persano Oddo L., Piazza M.G. (2002) Diagnosi matematica dei mieli uniflorali, in: Sabatini A.G., Bolchi Serini G., Frilli F., Porrini C., Il ruolo della ricerca in apicoltura, Litosei, Bologna, pp. 235-240.

Ruoff K. (2003) Solid-phase microextraction of honey volatiles: a method for the determination of the botanical origin of honey, Masters thesis, University of Helsinki.

Serra Bonvehí J. (1988) Determinacion de antranilato de metilo en la miel de citricos (Citrus sp.) del Levante Español, y su influencia en la actividad diastasica de la miel, Alimentaria 197, 37-40.

Serra Bonvehí J., Granados Tarrés E. (1993) Physicochemical properties, composition and pollen spectrum of ling heather (Calluna vulgaris) (L.) Hull honey produced in Spain, Apidologie 24, 586-596.

Serra Bonvehí J. Ventura Coll F. (1995) Characterization of Citrus honey (Citrus spp.) produced in Spain, XXXIV Int. Beekeep. Congr. Apimondia, Lausanne, pp. 358-364.

Talpay B. (1985) Spezifikazionen für Trachthonige, Dtsch. Lebensm. Rundsch. 81, 148-152.

Tomas-Barberan F.A., Martos I., Ferreres F., Radovic B.S., Anklam E. (2001) HPLC flavonoid profiles as markers for the botanical origin of European unifloral honeys, J. Sci. Food Agric. 81, 485-496.

Von der Ohe W.,Persano Oddo L., Piana M.L., Morlot M., Martin P. (2004) Harmonized methods of melissopalynology, Apidologie (Suppl. 1), S18S25.

White J.W., Bryant V.M. Jr. (1996) Assessing citrus honey quality: pollen and methyl anthranilate content, J. Agric. Food Chem. 44, 3423-3425. 


\section{RAPE HONEY}

(BRASSICA SPP. - BRASSICACEAE)

Rape (Brassica napus L. and other species, hybrids and varieties) is largely cultivated in Europe for the seed, used for oil production. It is very attractive to bees both for nectar and pollen and in Central and Eastern European countries represents one of the most important spring sources, giving rise to large amounts of very pure unifloral honey. The extension of cultivation and consequently the production of unifloral honey varies from year to year, according to European agricultural policy. In Northern Europe, e.g. Finland, the main Brassica honey is produced by turnip rape (Brassica rapa L. var. oleifera subvar. annua) (Ruoff, 2003). Outside Europe rape honey is produced in all the countries of the temperate area (mainly North America and China).

In many countries the unifloral denomination does not increase the market value and the honey is sold without mention of the botanical origin or it is blended with other honeys.

This honey is characterised by quick granulation, due to the high glucose content. For this property it is frequently used as a "crystallisation starter", added to other honeys to obtain a finer granulation.

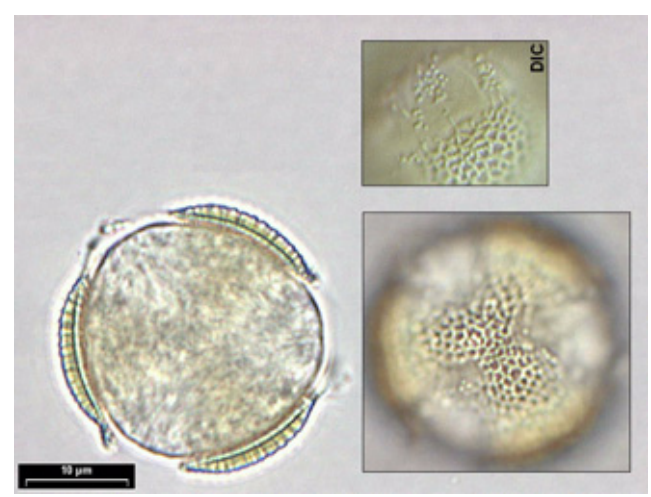

Rapeseed pollen is normally represented. The unifloral honey presents low values of electrical conductivity, proline and $\mathrm{F} / \mathrm{G}$ ratio, and high values of glucose, $\mathrm{F}+\mathrm{G}$ and $\mathrm{G} / \mathrm{W}$ ratio. For an authentic rapeseed honey some European laboratories requires a $\mathrm{F} / \mathrm{G}$ ratio lower than 1 (Russmann, personal communication).

\begin{tabular}{|c|c|c|}
\hline \multicolumn{3}{|c|}{ Sensory description } \\
\hline \multirow[t]{2}{*}{ Visual assessment } & \multicolumn{2}{|c|}{ Colour intensity: light } \\
\hline & \multicolumn{2}{|c|}{ Colour tone: normal honey colour } \\
\hline \multirow[t]{2}{*}{ Olfactory assessment } & \multicolumn{2}{|c|}{ Intensity of odour: medium } \\
\hline & \multicolumn{2}{|c|}{ Description: spoiled and vegetal } \\
\hline \multirow{5}{*}{ Tasting assessment } & Sweetness: medium & Acidity: weak \\
\hline & Bitterness: absent & Intensity of aroma: medium \\
\hline & \multicolumn{2}{|c|}{ Description of aroma: floral - fresh fruit (fruity), warm, spoiled and vegetal } \\
\hline & \multicolumn{2}{|c|}{ Persistencelaftertaste: short; aftertaste sometimes present (blackcurrant) } \\
\hline & \multicolumn{2}{|c|}{$\begin{array}{l}\text { Other mouth perceptions: when crystallised in very small crystals, refreshing (like } \\
\text { "fondant") }\end{array}$} \\
\hline Physical characteristics & \multicolumn{2}{|c|}{$\begin{array}{l}\text { Crystallisation rate: quick } \\
\text { Other: this honey is often in crystallised form with very small crystals; in this case } \\
\text { the colour appears whitish or dull ivory }\end{array}$} \\
\hline
\end{tabular}



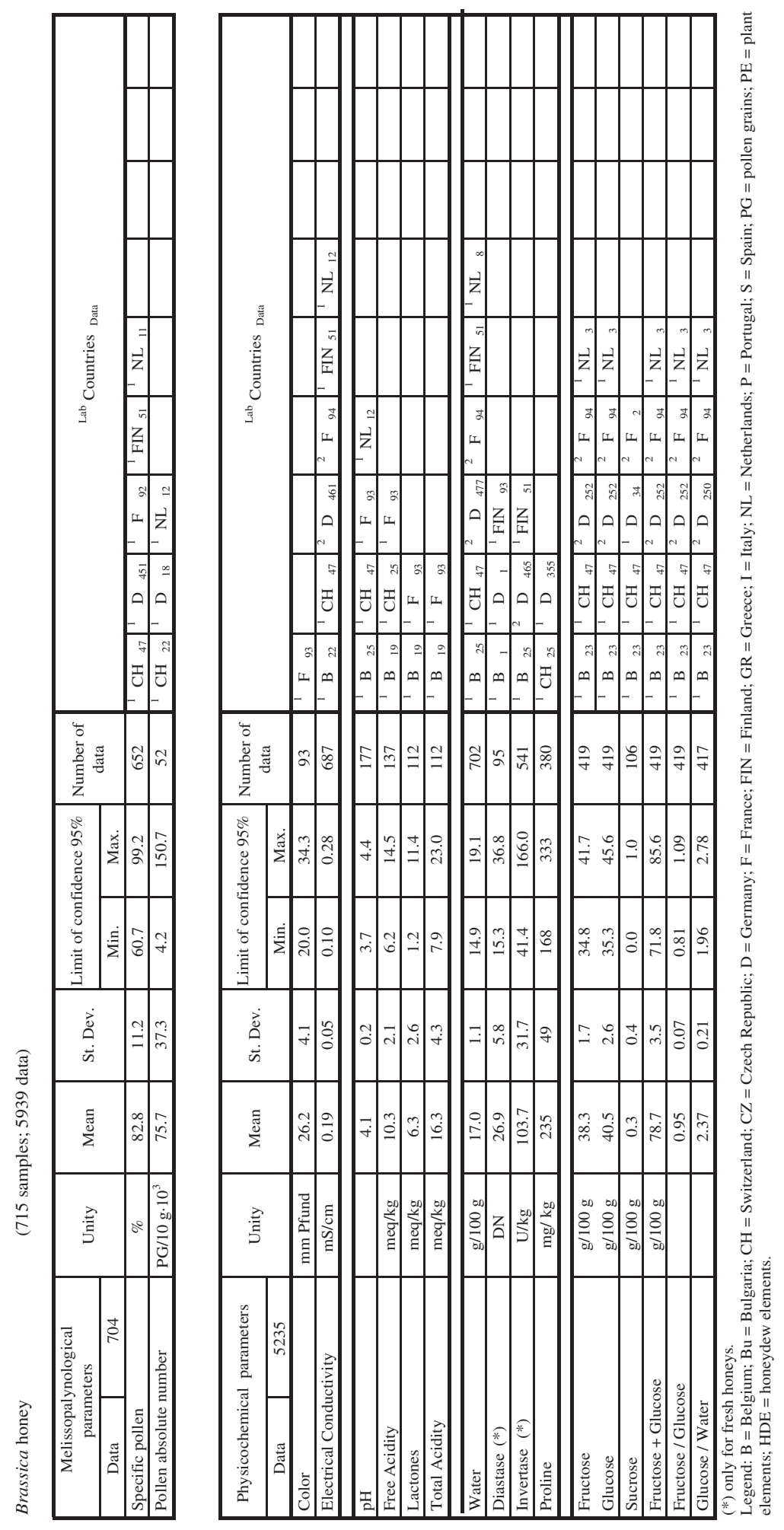


\section{HEATHER HONEY \\ (CALLUNA VULGARIS (L.) HULL - ERICACEAE)}

Calluna vulgaris (heather) is widely distributed in the Northern and Western countries of Europe, where it represents one of the most important resources for honey production in the late summer.

Heather honey is characterised by a particular physical phenomenon, called thixotropy: due to the presence of colloidal proteins, it becomes of a jelly consistence. This property makes the extraction from the combs only possible with the help of special tools (provided with needles that, mixing the honey in each comb cell, turn it into a sol state). A high water content, due to the season of production and the quick increase of HMF, due to a high acidity level, make the shelf-life of this honey shorter than other honey types.

The melissopalynological characteristics of Calluna honey are very variable: from the PG/10 g value (mostly between 20000 and 100000 , II class of representativity) it seems to be normally represented, but the pollen percent is often under the $45 \%$ limit. This behaviour may be accounted for by the particular extraction technique (Louveaux, 1970).

The unifloral honey shows high values of colour, water and acidity; also electrical conductivity is one of the highest among nectar honeys, apart from chestnut honey. The European Directive allows a water content of up to

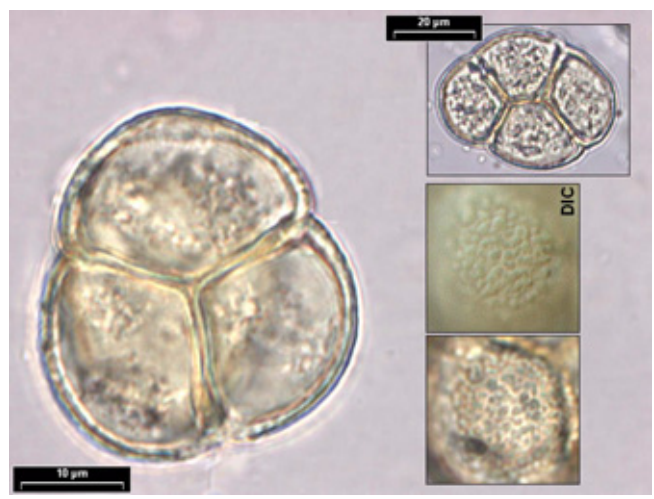

$23 \mathrm{~g} / 100 \mathrm{~g}$ and includes this honey in a group whose electrical conductivity may go beyond the $0.8 \mathrm{mS} / \mathrm{cm}$ limit.

A chemical marker for this honey type could be represented by the high content of total protein (Serra Bonvehí and Granados Tarrés, 1993). One European laboratory accept as unifloral only honeys whose protein content is above $1.15 \mathrm{~g} / 100 \mathrm{~g}$ (Russmann, personal communication). Another element of characterisation can be the typical thixotropy, measurable through a viscosimeter (Serra Bonvehí and Granados Tarrés, 1993) or a thixotropic test (Louveaux, 1967).

\begin{tabular}{|c|c|c|}
\hline \multicolumn{3}{|c|}{ Sensory description } \\
\hline \multirow{2}{*}{ Visual assessment } & \multicolumn{2}{|c|}{ Colour intensity: dark to very dark } \\
\hline & \multicolumn{2}{|c|}{ Colour tone: normal honey colour with reddish/orange tone } \\
\hline \multirow[t]{2}{*}{ Olfactory assessment } & \multicolumn{2}{|c|}{ Intensity of odour: medium to strong } \\
\hline & \multicolumn{2}{|c|}{ Description: woody, floral - fresh fruit, warm } \\
\hline \multirow{5}{*}{ Tasting assessment } & Sweetness: weak & Acidity: medium \\
\hline & Bitterness: medium & Intensity of aroma: strong \\
\hline & \multicolumn{2}{|c|}{ Description of aroma: floral - fresh fruit, warm } \\
\hline & \multicolumn{2}{|c|}{ Persistence/aftertaste: long } \\
\hline & \multicolumn{2}{|c|}{ Other mouth perceptions: - } \\
\hline Physical characteristics & \multicolumn{2}{|c|}{$\begin{array}{l}\text { Crystallisation rate: moderate } \\
\text { Other: it often forms big rounded crystals; when liquid, the typical gel consistency is one } \\
\text { of the diagnostic characteristics }\end{array}$} \\
\hline
\end{tabular}



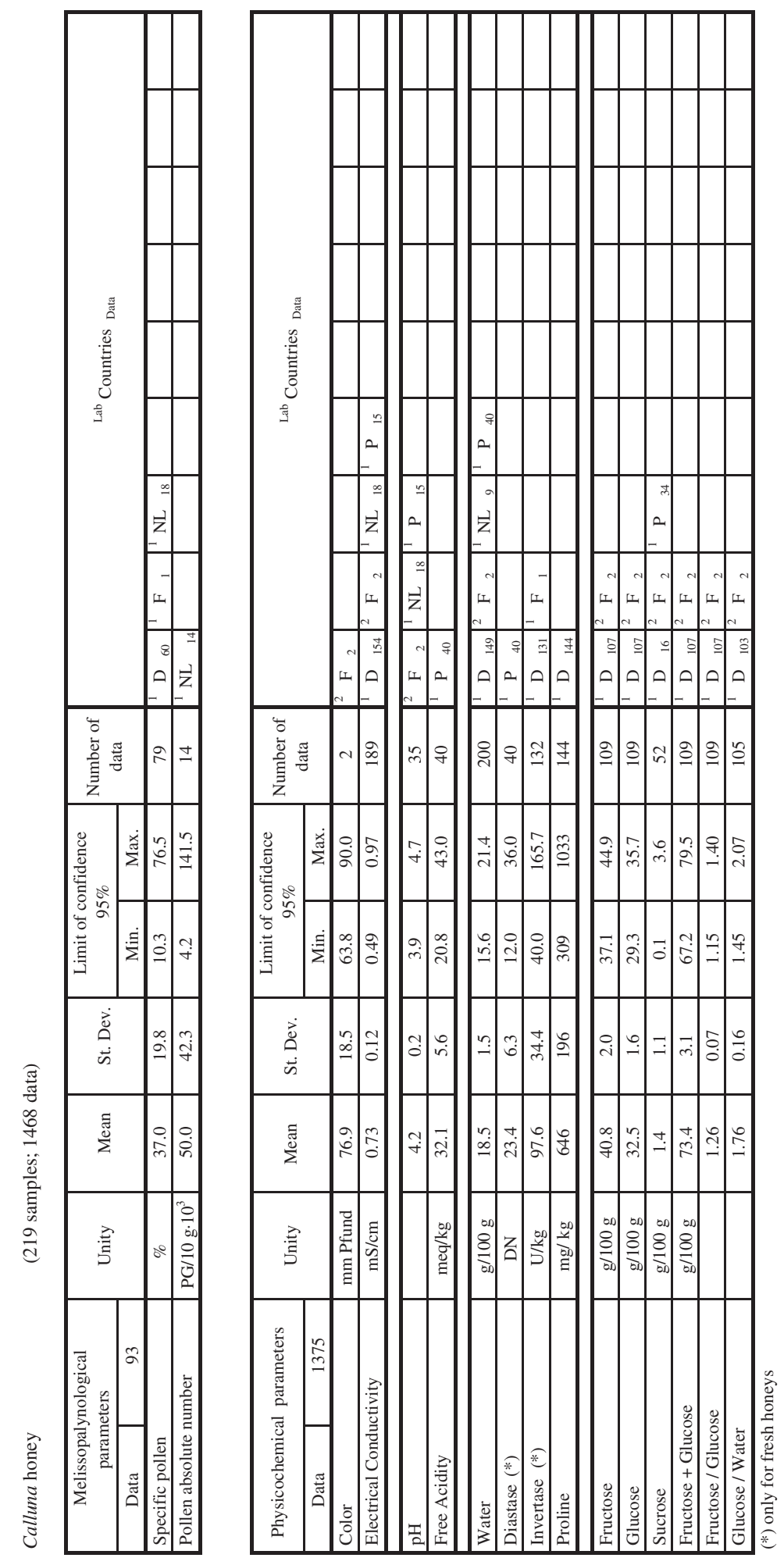


\section{CHESTNUT HONEY \\ (CASTANEA SATIVA MILLER - FAGACEAE)}

Castanea sativa is found in many European countries, mostly Central and Southern ones and between 500 and $1000 \mathrm{~m}$ above sea level, spontaneous or cultivated for nuts and wood production. It represents for honey bees one of the best sources of nectar and pollen, but it can also provide honeydew, following the attack by some insects belonging to Rhynchota Homoptera: Lachnus roboris L. (Lachnidae), Myzocallis castanicola (Baker) (Callaphididae), Parthenolecanium rufulum (Cockrell) (Coccidae).

Pure chestnut honeys remain for a long time in a liquid state, due to the high fructose and low glucose content. Castanea pollen is strongly over-represented, and many laboratories require a percentage of at least $90 \%$, with more than 100000 PG/10 g honey, before accepting the honey as unifloral. This honey shows quite a typical physicochemical pattern, with low values of G/W ratio and high values of colour, electric conductivity, enzymes, $\mathrm{pH}$ and $\mathrm{F} / \mathrm{G}$ ratio. For this honey the European Directive requires a value of electrical conductivity higher than $0.8 \mathrm{mS} / \mathrm{cm}$.

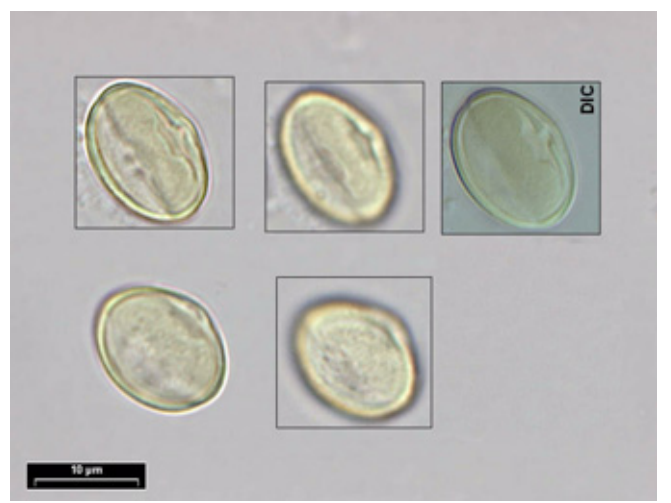

In the IHC data collection, data from one French laboratory show different fructose and glucose values, resulting in a lower average fructose/glucose ratio ( $1.19 \pm 0.07)$; excluding these values, the F/G mean value resulting from the remaining data would increase from $1.48 \pm 0.19$ to $1.56 \pm 0.11$.

\begin{tabular}{|c|c|c|}
\hline \multicolumn{3}{|c|}{ Sensory description } \\
\hline \multirow[t]{2}{*}{ Visual assessment } & \multicolumn{2}{|c|}{ Colour intensity: dark to very dark } \\
\hline & \multicolumn{2}{|c|}{ Colour tone: normal honey colour with reddish tone } \\
\hline \multirow[t]{2}{*}{ Olfactory assessment } & \multicolumn{2}{|c|}{ Intensity of odour: strong } \\
\hline & \multicolumn{2}{|c|}{ Description: woody, chemical, warm } \\
\hline \multirow[t]{5}{*}{ Tasting assessment } & Sweetness: weak & Acidity: weak \\
\hline & Bitterness: strong & Intensity of aroma: strong \\
\hline & \multicolumn{2}{|c|}{ Description of aroma: woody, chemical, warm and spoiled } \\
\hline & \multicolumn{2}{|c|}{ Persistencelaftertaste: long } \\
\hline & \multicolumn{2}{|c|}{ Other mouth perceptions: astringent } \\
\hline Physical characteristics & \multicolumn{2}{|c|}{$\begin{array}{l}\text { Crystallisation rate: slow } \\
\text { Other: it is quite common a fluid consistency, due to a high water content }\end{array}$} \\
\hline
\end{tabular}



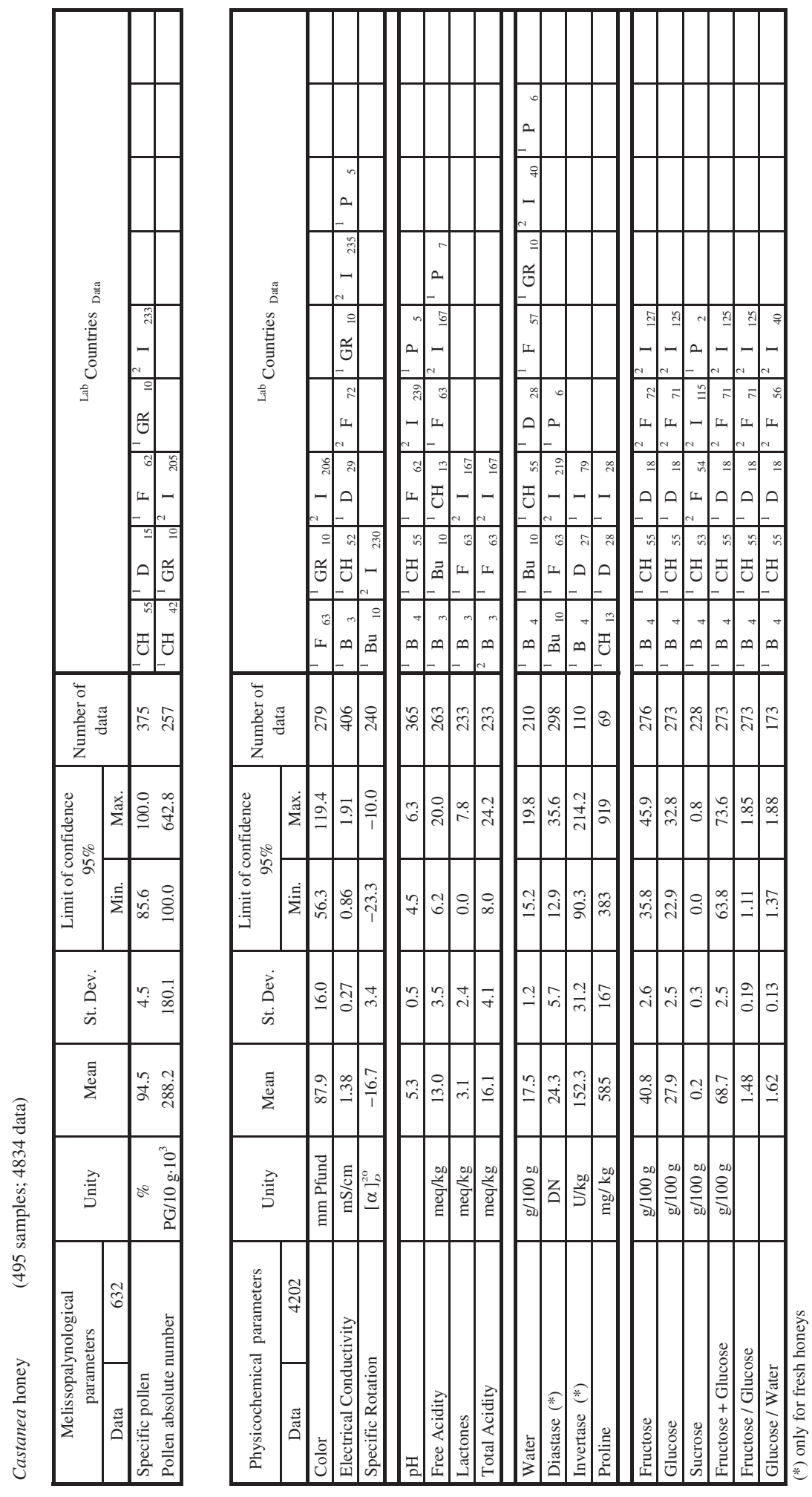


\section{CITRUS HONEY (CITRUS SPP. - RUTACEAE)}

Different species, hybrids, varieties and cultivars of Citrus are cultivated in Mediterranean countries for the production of fruits and aromatic essences. All of them are very attractive to bees and give rise to large amounts of unifloral honey, mainly in Spain and Italy. The honey has a high commercial value and is the object of an import-export market.

Out of Europe the main producers of Citrus honey are Israel, USA (California), Brazil and Mexico, from where it is also imported into Europe.

Physicochemical characteristics of honeys from the various species are similar and one overall class is considered here, referred to Citrus spp.

Citrus pollen is under-represented, at a lesser or greater extent depending on the different species and cultivars. The unifloral honey shows low values of colour, electrical conductivity, enzymes, and a slightly high content of sucrose. In the European Directive, a diastase number as low as 3 and a sucrose content up to $10 \mathrm{~g} / 100 \mathrm{~g}$ are allowed for this honey. However, in the IHC data collection only 2 samples had a sucrose content higher than the limit of $5 \mathrm{~g} / 100 \mathrm{~g}$.

Methylanthranilate is a chemical "marker" for Citrus unifloral honey (Talpay, 1985; Serra Bonvehí, 1988; Serra Bonvehí and Ventura Coll, 1995; White and Bryant, 1996); German

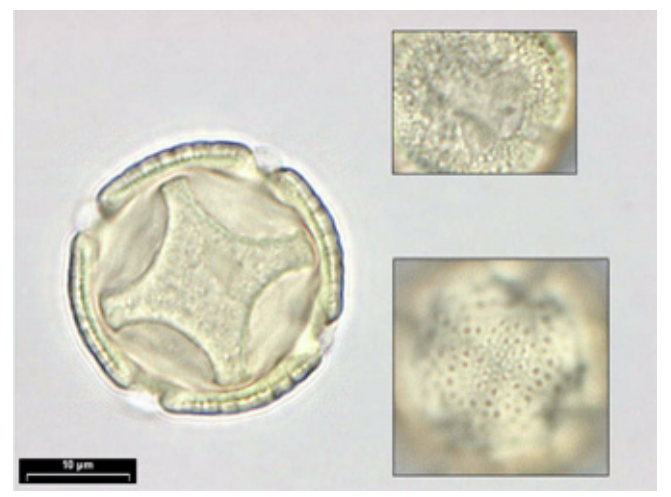

laboratories consider a content of at least $2 \mathrm{mg} / \mathrm{kg}$ as typical for an authentic unifloral honey (Talpay, 1985; Russmann, personal communication). The flavonoid "hesperitin" is also reported as a marker for Citrus unifloral honey by Ferreres et al. (1993) and Tomas-Barberan et al. (2001).

In the IHC data collection a considerable difference was recorded in proline values between Greece $(769 \mathrm{mg} / \mathrm{kg} \pm 157)$ and Italy $(232 \mathrm{mg} / \mathrm{kg}$ \pm 95 ). Since no other countries provided data for proline this parameter was omitted from the physico-chemical table.

\begin{tabular}{|c|c|c|}
\hline \multicolumn{3}{|c|}{ Sensory description } \\
\hline \multirow[t]{2}{*}{ Visual assessment } & \multicolumn{2}{|c|}{ Colour intensity: very light } \\
\hline & \multicolumn{2}{|c|}{ Colour tone: normal honey colour } \\
\hline \multirow[t]{2}{*}{ Olfactory assessment } & \multicolumn{2}{|c|}{ Intensity of odour: medium } \\
\hline & \multicolumn{2}{|c|}{ Description: floral - fresh fruit (floral) } \\
\hline \multirow[t]{5}{*}{ Tasting assessment } & Sweetness: medium & Acidity: weak \\
\hline & Bitterness: absent & Intensity of aroma: medium \\
\hline & \multicolumn{2}{|c|}{ Description of aroma: fresh (anise), floral - fresh fruit (floral) } \\
\hline & \multicolumn{2}{|c|}{ Persistencelaftertaste: short to medium } \\
\hline & \multicolumn{2}{|c|}{ Other mouth perceptions: - } \\
\hline Physical characteristics & \multicolumn{2}{|c|}{ Crystallisation rate: moderate } \\
\hline
\end{tabular}



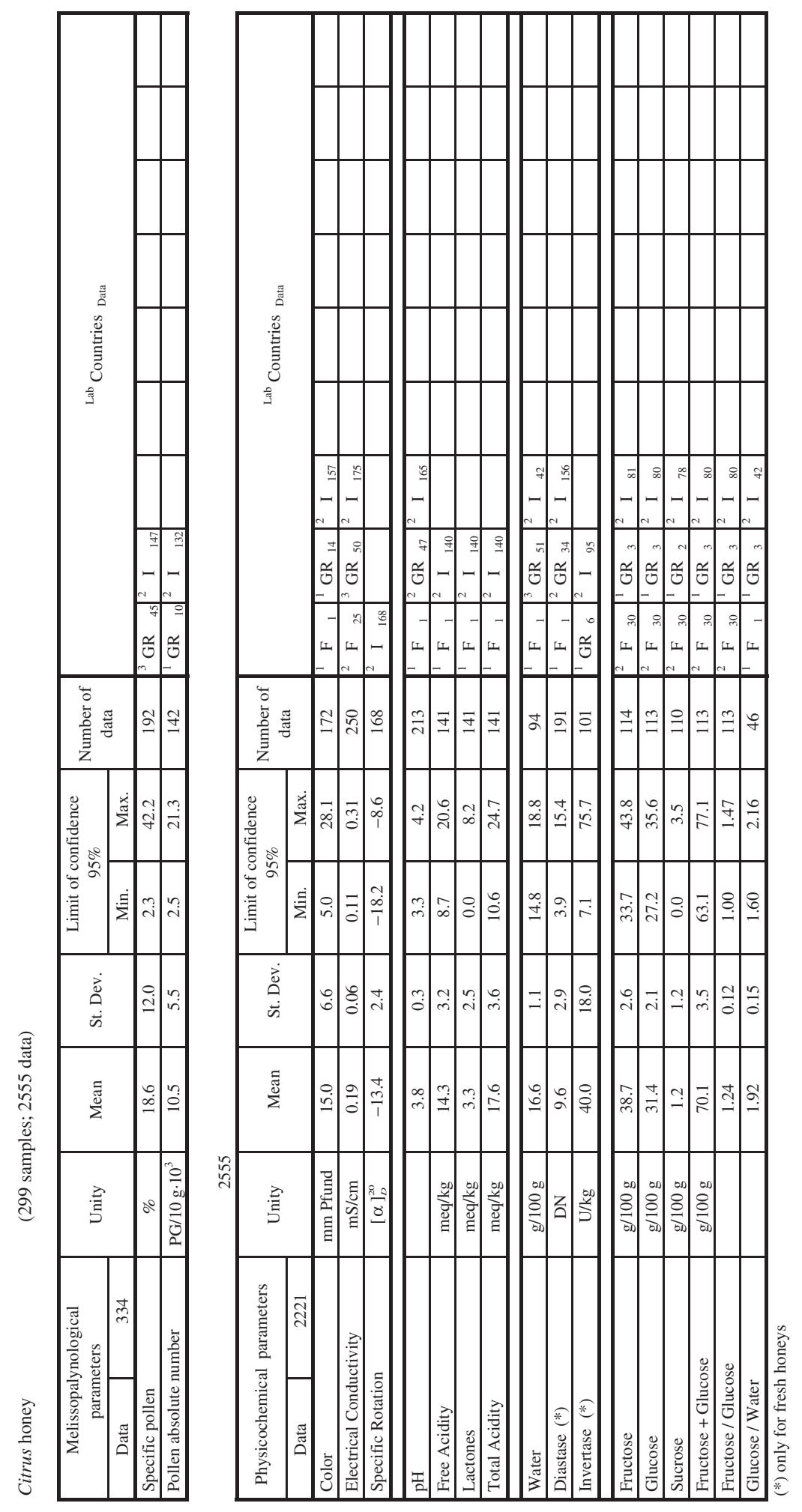


\section{EUCALYPTUS HONEY (EUCALYPTUS SPP. - MYRTACEAE)}

Various Eucalyptus species, introduced from Australia at the beginning of the twentieth century, are found in the Mediterranean countries of Europe, cultivated mainly along the coasts (the tree has a good resistance to the coastal climate), for the paper industry, for the essential oil and as ornamental species. E. camaldulensis Dehn is one of the most important, but all species are very attractive to bees that gather from them both nectar and pollen.

The unifloral honey production is important in Italy, Spain and Portugal. Outside Europe, large amounts of Eucalyptus honey are produced in the countries where these species come from (Australia and New Zealand) or are introduced (North and South Africa, Israel, Central and Southern America).

E. camaldulensis pollen is over-represented (usually, Italian laboratories consider that for authentic honeys, at least $90 \%$ of specific pollen is typical). Unifloral honey has slightly high values of diastase, invertase and $\mathrm{G} / \mathrm{W}$ ratio (due to a low water content rather than high glucose content). The European Directive includes Eucalyptus honey in a group whose electrical

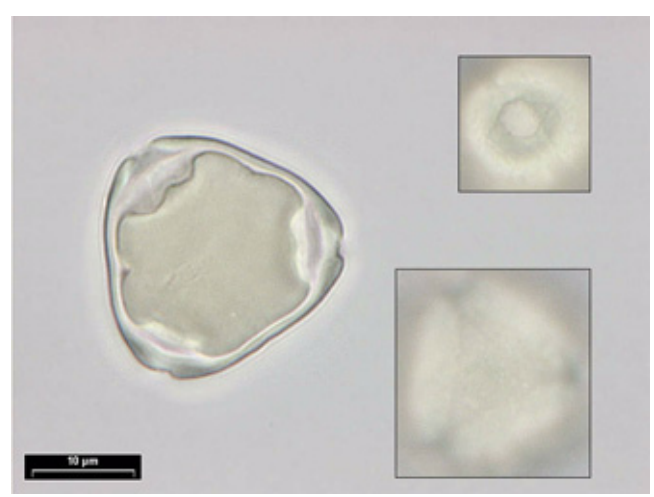

conductivity may go beyond the $0.8 \mathrm{mS} / \mathrm{cm}$ limit, and allows for this honey a sucrose content up to $10 \mathrm{~g} / 100 \mathrm{~g}$. However, in samples collected by IHC, the highest value of electrical conductivity was about $0.6 \mathrm{mS} / \mathrm{cm}$, and no sucrose values were recorded above the $5 \mathrm{~g} /$ $100 \mathrm{~g}$ limit. Indeed, the Directive takes into account Eucalyptus honeys from non-European countries, that may have different values (Bogdanov et al., 1999).

\begin{tabular}{|c|c|c|}
\hline \multicolumn{3}{|c|}{ Sensory description } \\
\hline \multirow[t]{2}{*}{ Visual assessment } & \multicolumn{2}{|c|}{ Colour intensity: medium to dark } \\
\hline & \multicolumn{2}{|c|}{ Colour tone: normal honey colour with dull tone (greyish) } \\
\hline \multirow[t]{2}{*}{ Olfactory assessment } & \multicolumn{2}{|c|}{ Intensity of odour: medium to strong } \\
\hline & \multicolumn{2}{|c|}{ Description: warm and spoiled } \\
\hline \multirow[t]{5}{*}{ Tasting assessment } & Sweetness: medium & Acidity: weak \\
\hline & Bitterness: absent & Intensity of aroma: medium \\
\hline & \multicolumn{2}{|c|}{ Description of aroma: woody, warm and spoiled } \\
\hline & \multicolumn{2}{|c|}{ Persistence/aftertaste: medium } \\
\hline & \multicolumn{2}{|c|}{ Other mouth perceptions: - } \\
\hline Physical characteristics & \multicolumn{2}{|c|}{ Crystallisation rate: moderate } \\
\hline
\end{tabular}




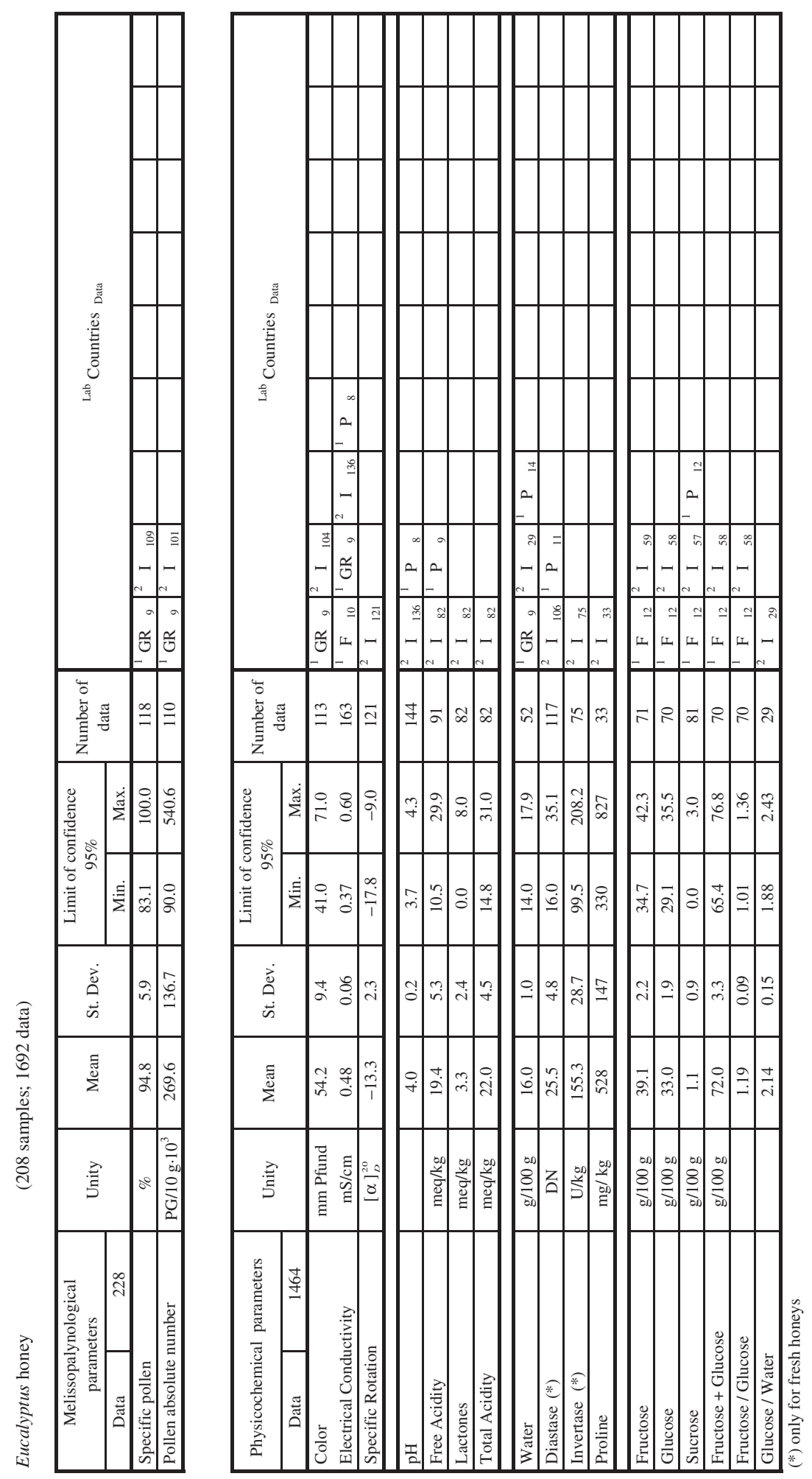




\section{SUNFLOWER HONEY \\ (HELIANTHUS ANNUUS L. - ASTERACEAE)}

Sunflower is largely cultivated for the oily seeds in many European countries, above all in Eastern and Southern ones, where it represents to bees an important source of nectar and pollen. The extension of cultivation and consequently the production of unifloral honey varies from year to year according to the European agricultural policy.

At present the unifloral denomination does not add market value to this honey, and in some countries it is not labelled as unifloral or it is blended with multifloral honeys.

The unifloral honey has a quick and often hard crystallisation, due to the high glucose content.

A big variability was recorded in the Helianthus pollen content, from less than $20 \%$ to more than $90 \%$, with a PG/10 g value mostly below 30000 . The morphology of flower and pollen grains do not justify any under-represented behaviour, but different varieties or cultivars may have a variable pollen production.

Apart from its bright yellow colour, Helianthus unifloral honey is characterised by slightly

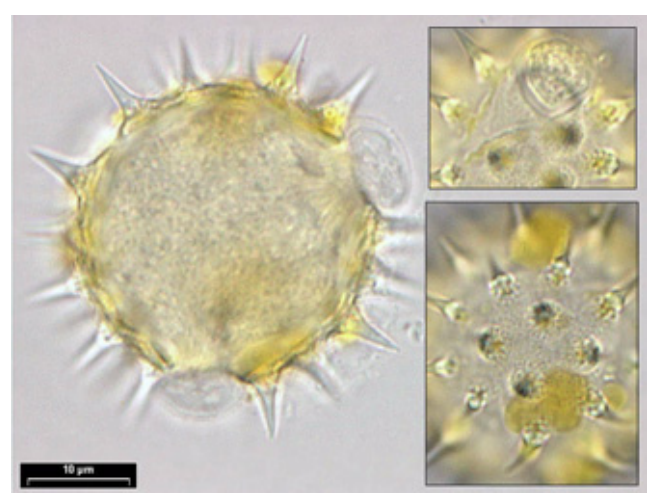

high proline and acidity values and by a typical sugar spectrum, with a high glucose content, leading to a high $\mathrm{F}+\mathrm{G}$ and a low $\mathrm{F} / \mathrm{G}$ ratio. $\mathrm{G} / \mathrm{W}$ ratio is quite elevated, but not at the highest levels, because of an often high water content. Low values were also recorded for sucrose and other oligosaccharides (Persano Oddo et al., 2000).

\begin{tabular}{|l|l|l|}
\hline \multicolumn{2}{|c|}{ Sensory description } \\
\hline Visual assessment & Colour intensity: medium \\
\cline { 2 - 3 } & Colour tone: bright yellow \\
\hline Olfactory assessment & Intensity of odour: weak & Acidity: strong \\
\cline { 2 - 3 } Tasting assessment & Description: floral - fresh fruit (fruity), warm and vegetal \\
\cline { 2 - 3 } & Sweetness: medium & Intensity of aroma: weak to medium \\
\cline { 2 - 3 } & Bitterness: absent & Description of aroma: floral - fresh fruit (fruity), warm and vegetal \\
\cline { 2 - 3 } & Persistence/aftertaste: short \\
\cline { 2 - 3 } & $\begin{array}{l}\text { Other mouth perceptions: when crystallised with very small crystals, refreshing (like } \\
\text { "fondant") }\end{array}$ \\
\hline Physical characteristics & $\begin{array}{l}\text { Crystallisation rate: } \text { quick } \\
\text { Other: crystallisation with hard crystals (hardly soluble) is frequent }\end{array}$ \\
\hline
\end{tabular}



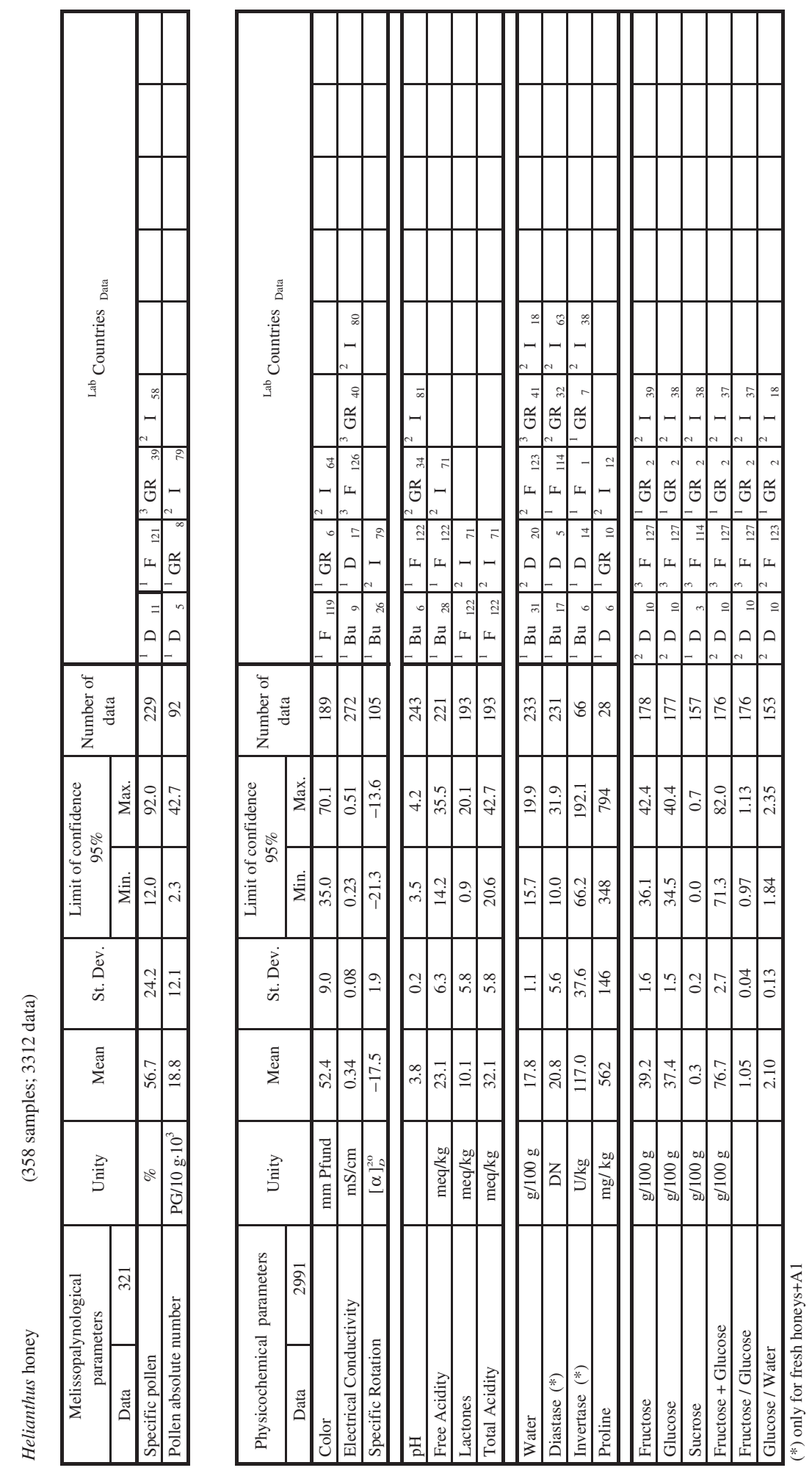


\section{LAVANDER HONEY (LAVANDULA SPP. - LAMIACEAE)}

Lavandula unifloral honey is mainly produced from the hybrid L. $x$ intermedia Emeric ex Loiselieur, cultivated for the essential oil in France, Spain and, to a lesser extent, in other Southern and Mediterranean countries. It is extremely attractive to bees and represents a very valuable resource for honey production; Lavander honey also has a high commercial value and is marketed internationally.

Unifloral honey can be produced also from other Lavandula species: L. angustifolia Miller (France and Spain), L. latifolia Medicus (Spain and France) and L. stoechas L. (Spain, Portugal and Italy). In the IHC data collection, the first one showed a physicochemical pattern quite similar to L. x intermedia, therefore one overall class was considered, referred to Lavandula spp. Different characteristics were recorded for L. latifolia and L. stoechas honeys, that are not described here, since their production is mostly of local interest.

L. $x$ intermedia pollen is strongly under-represented and even absent. The physicochemical

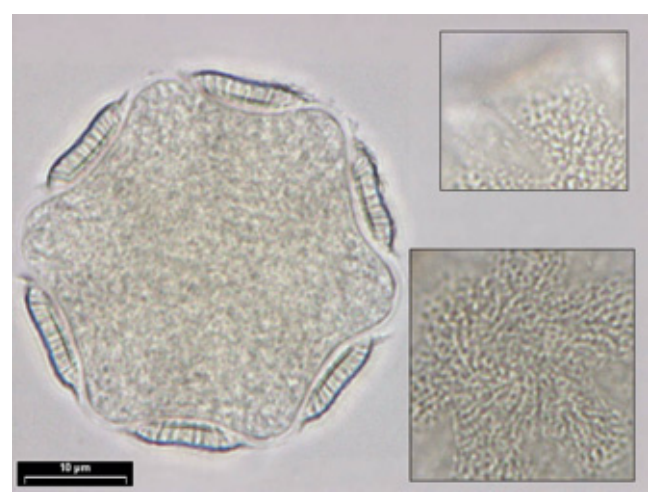

pattern of Lavander unifloral honey is characterised by low values of electrical conductivity, slightly low $\mathrm{F}+\mathrm{G}$ and high values of sucrose. For this honey the European Directive allows a sucrose content up to $15 \mathrm{~g} / 100 \mathrm{~g}$.

\begin{tabular}{|l|l|l|}
\hline \multicolumn{2}{|c|}{ Sensory description } \\
\hline Visual assessment & Colour intensity: light \\
\cline { 2 - 3 } & Colour tone: normal honey colour, with bright tone (yellow) \\
\hline Olfactory assessment & Intensity of odour: medium & Acidity: medium \\
\cline { 2 - 3 } & Description: woody, floral - fresh fruit (floral) and vegetal \\
\hline Tasting assessment & Sweetness: medium & Intensity of aroma: medium \\
\cline { 2 - 3 } & Bitterness: absent & \\
\cline { 2 - 2 } & Description of aroma: woody, fresh, floral - fresh fruit and warm \\
\cline { 2 - 2 } & Persistence/aftertaste: medium \\
\cline { 2 - 2 } & Other mouth perceptions: aftertaste sometimes present (blackcurrant) \\
\hline Physical characteristics & Crystallisation rate: moderate \\
\hline
\end{tabular}




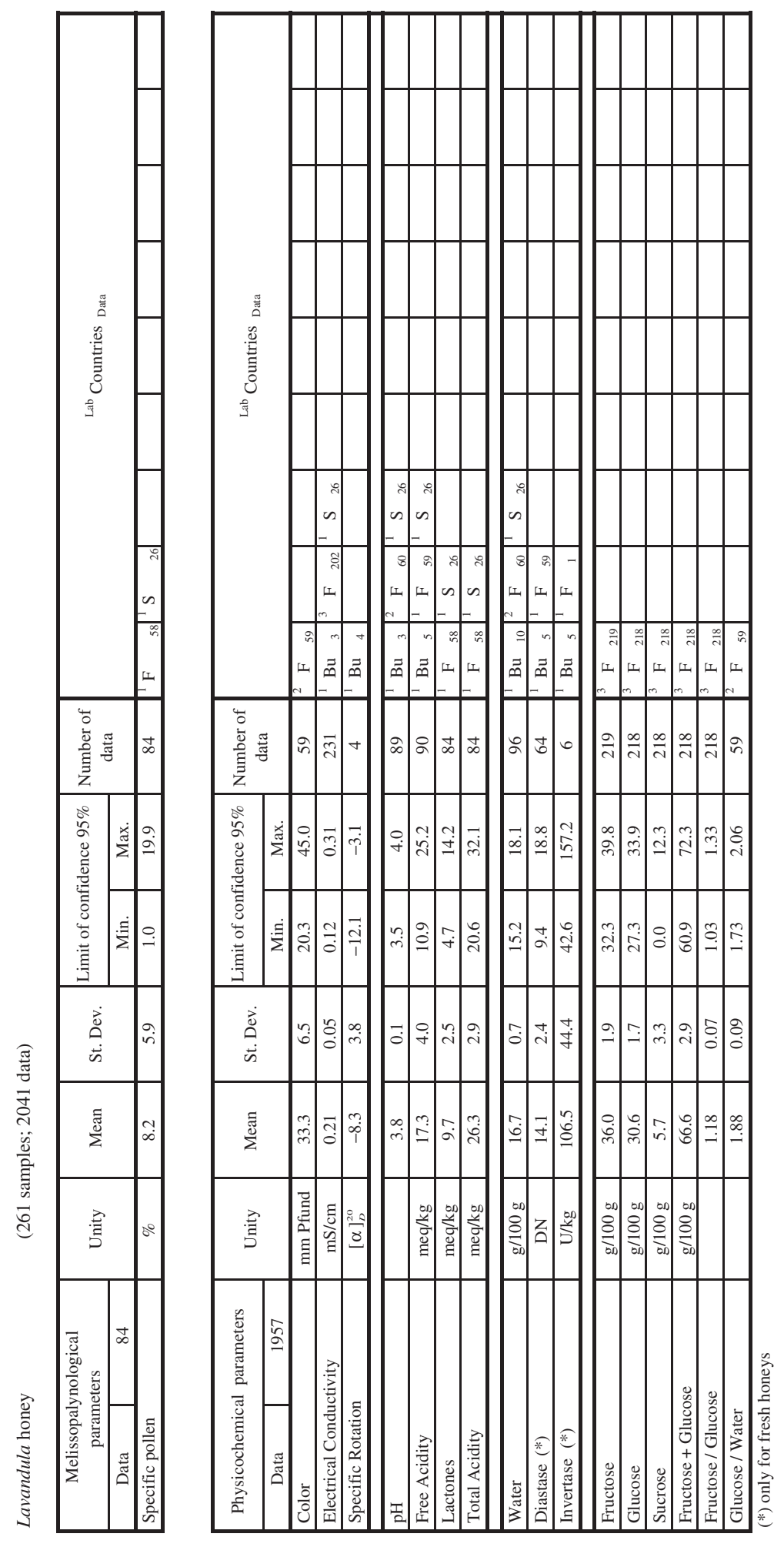




\section{RHODODENDRON HONEY (RHODODENDRON SPP - ERICACEAE)}

Rhododendron honey originates from the species and natural hybrids spread in the Alps and Pyrenees: $R$. ferrugineum L., $R$. hirsutum L. and their hybrid $R$. x intermedium. One overall class is considered here, referred to as Rhododendron spp.

The unifloral honey is produced exclusively at an altitude where bees can stay only during some months, therefore the seasonal migration of hives is always required. The harvest is not abundant (or even certain), because of the variable meteorological conditions, and does not meet the demand. It is mostly sold in the production areas. Its market value is elevated and this may encourage an incorrect use of the denomination.

Rhododendron pollen is under-represented (PG/10 g < 20000 ), but relatively high percentages of the specific pollen are not rare. The uni-

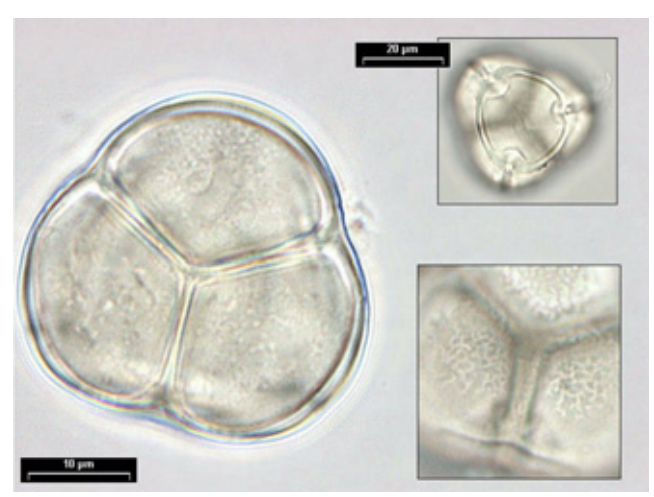

floral honey shows low values of colour, electrical conductivity and proline, and moderately negative values of specific rotation.

\begin{tabular}{|c|c|c|}
\hline \multicolumn{3}{|c|}{ Sensory description } \\
\hline \multirow[t]{2}{*}{ Visual assessment } & \multicolumn{2}{|c|}{ Colour intensity: very light } \\
\hline & \multicolumn{2}{|c|}{ Colour tone: normal honey colour } \\
\hline \multirow[t]{2}{*}{ Olfactory assessment } & \multicolumn{2}{|c|}{ Intensity of odour: weak } \\
\hline & \multicolumn{2}{|c|}{ Description: woody and floral - fresh fruit } \\
\hline \multirow[t]{5}{*}{ Tasting assessment } & Sweetness: medium & Acidity: weak \\
\hline & Bitterness: absent & Intensity of aroma: weak \\
\hline & \multicolumn{2}{|c|}{ Description of aroma: woody, fresh, floral - fresh fruit (fruity) and warm } \\
\hline & \multicolumn{2}{|c|}{ Persistencelaftertaste: short } \\
\hline & \multicolumn{2}{|c|}{ Other mouth perceptions: - } \\
\hline Physical characteristics & \multicolumn{2}{|c|}{ Crystallisation rate: moderate } \\
\hline
\end{tabular}



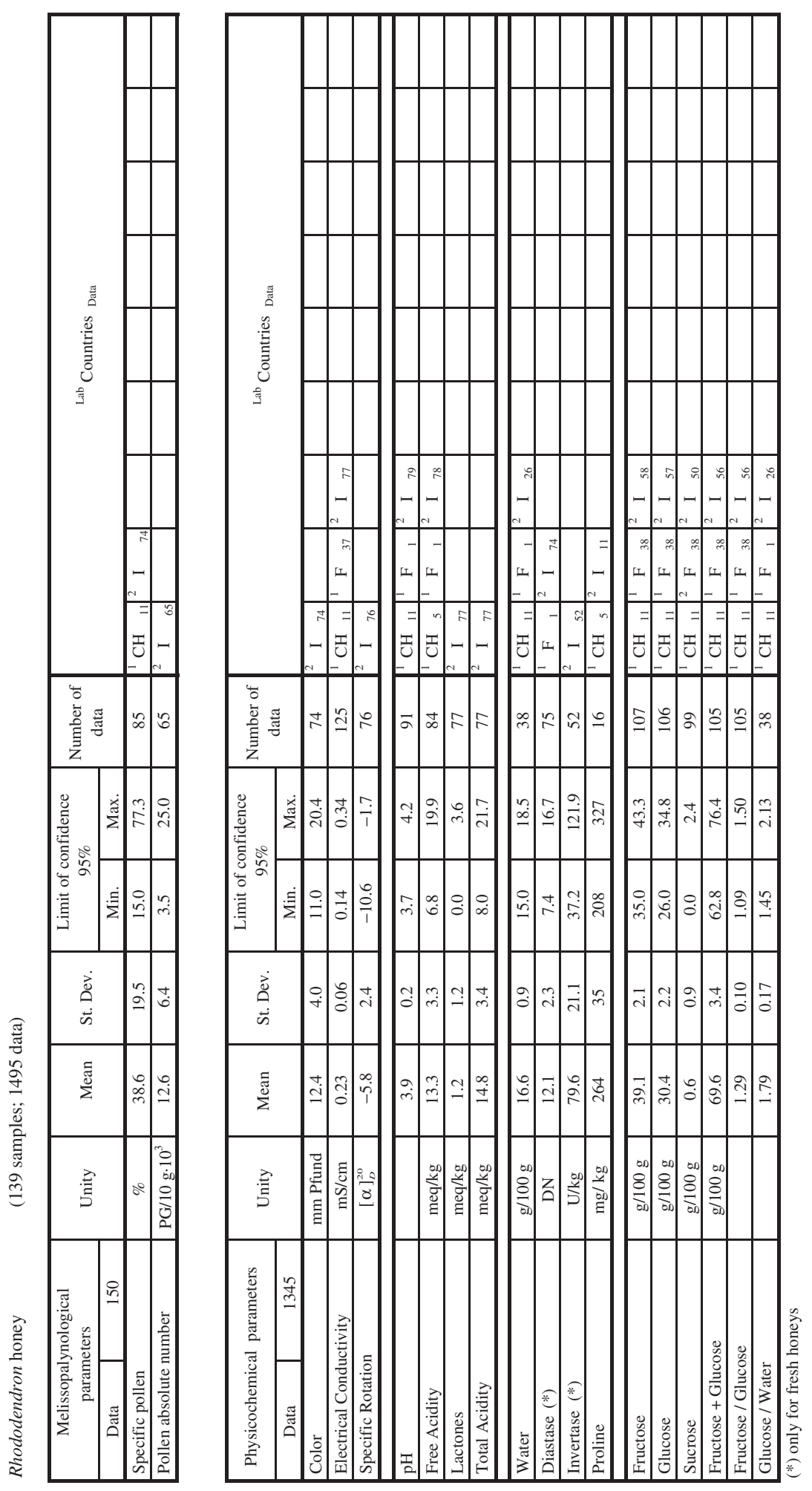


\section{BLACK LOCUST HONEY (ROBINIA PSEUDOACACIA L. - FABACEAE)}

Robinia pseudoacacia, native to the Northeast United States, is widely naturalised and cultivated in Europe. Important amounts of Robinia unifloral honey (often incorrectly called Acacia honey) are produced in many European countries, mainly in the Eastern ones, where the major quantities come from. Outside Europe, the Robinia honey is produced mostly in China.

Robinia honey is one of the most valuables honey types on the European market, because its characteristics are very much appreciated by the consumer: liquid (due to the high fructose content) and very light coloured and flavoured. These characteristics may easily be spoiled by the presence of foreign nectars or honeydew components, even in small quantities.

Robinia pollen is under-represented. The unifloral honey has quite a typical pattern, with low values of electrical conductivity, colour, acidity, enzymes, proline, glucose and G/W ratio and high values of fructose, sucrose and F/G ratio. For accepting a Robinia honey as unifloral, one European laboratory requires a $\mathrm{F} / \mathrm{G}$ ratio of at least 1.55 (Russmann, personal communication). According to the European Directive a content of sucrose up to $10 \mathrm{~g} / 100 \mathrm{~g}$ is permitted for this honey; moreover, it can be included in the category of honeys with a low

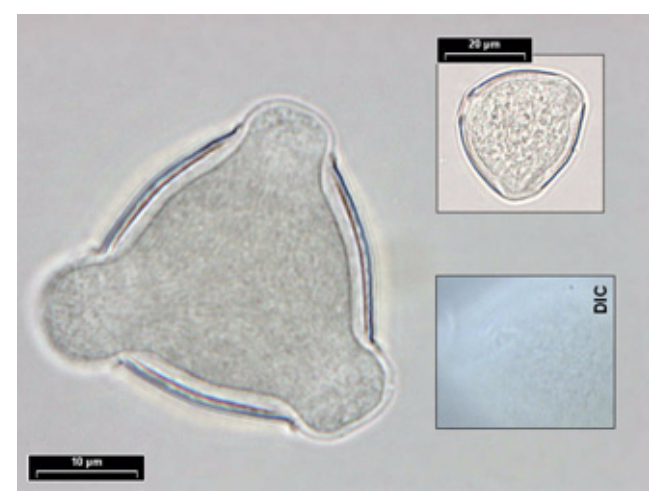

enzyme content, for which a minimum diastase number of 3 is allowed.

In the IHC data collection, data from one French laboratory show slightly different fructose and glucose values, resulting in a lower average fructose/glucose ratio $(1.49 \pm 0.06)$; excluding these values, the $F / G$ mean value resulting from the remaining data would increase from $1.61 \pm 0.11$ to $1.65 \pm 0.10$.

\begin{tabular}{|c|c|c|}
\hline \multicolumn{3}{|c|}{ Sensory description } \\
\hline \multirow[t]{2}{*}{ Visual assessment } & \multicolumn{2}{|l|}{ Colour intensity: very light } \\
\hline & \multicolumn{2}{|c|}{ Colour tone: normal honey colour } \\
\hline \multirow[t]{2}{*}{ Olfactory assessment } & \multicolumn{2}{|l|}{ Intensity of odour: weak } \\
\hline & \multicolumn{2}{|c|}{ Description: floral - fresh fruit and warm } \\
\hline \multirow[t]{5}{*}{ Tasting assessment } & Sweetness: medium to strong & Acidity: weak \\
\hline & Bitterness: absent & Intensity of aroma: weak \\
\hline & \multicolumn{2}{|c|}{ Description of aroma: floral - fresh fruit and warm } \\
\hline & \multicolumn{2}{|l|}{ Persistence/aftertaste: short } \\
\hline & \multicolumn{2}{|l|}{ Other mouth perceptions: - } \\
\hline Physical characteristics & \multicolumn{2}{|l|}{ Crystallisation rate: slow } \\
\hline
\end{tabular}



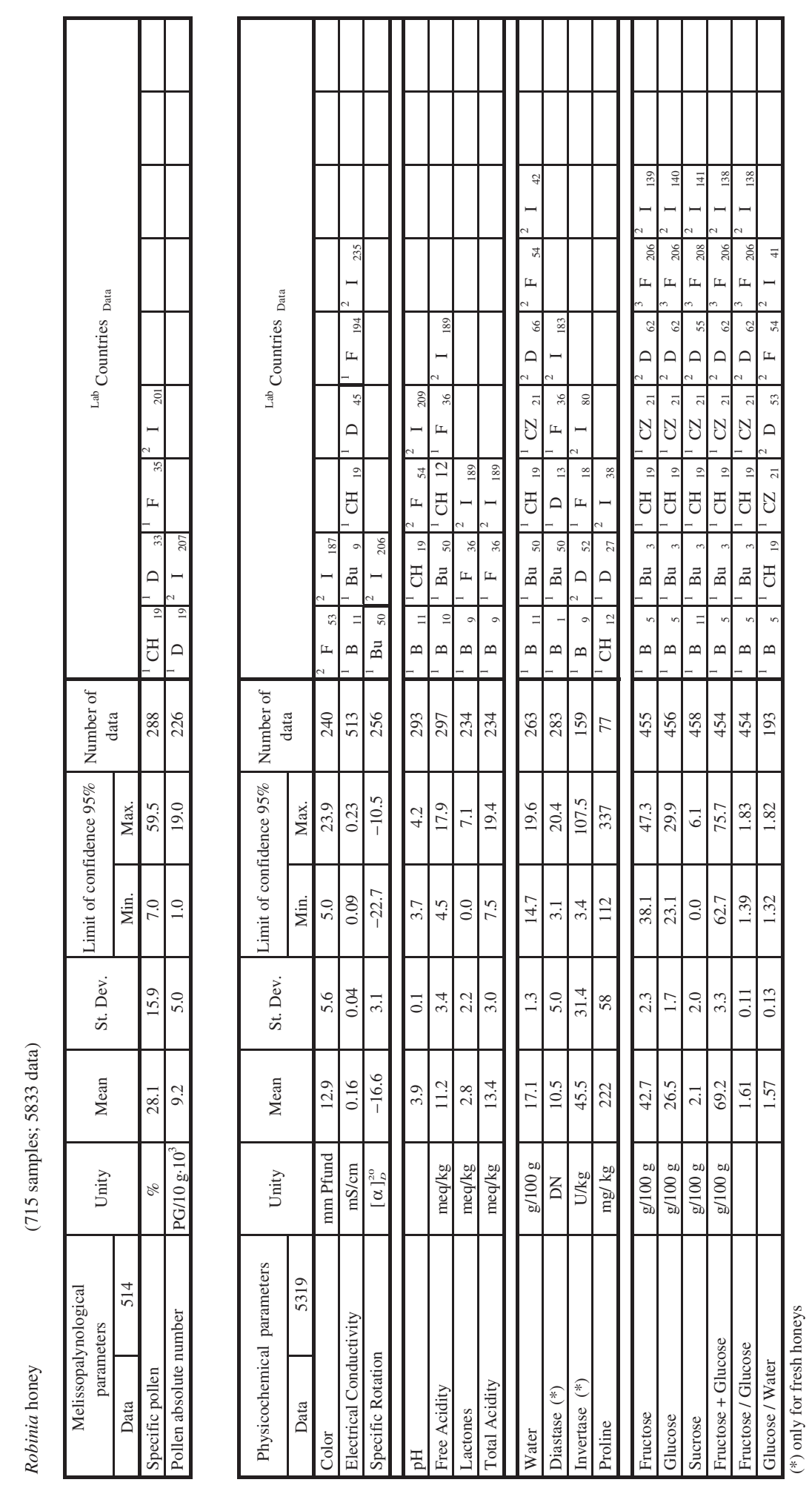


\section{ROSEMARY HONEY \\ (ROSMARINUS OFFICINALIS L. - LAMIACEAE)}

Rosmarinus officinalis is a typical plant of the Mediterranean vegetation. Spontaneous along the coasts, it is also cultivated as an aromatic plant in a wider area. It is very attractive to bees, but as the main flow is in early spring, a good exploitation of this very valuable nectar source is not always possible.

The unifloral honey is produced in the Mediterranean countries of Europe (mainly in Spain), North Africa and Turkey. It is appreciated by the consumer for its fine flavour and has a good commercial value.

The pollen of Rosmarinus is under-represented. The unifloral honey shows low values for colour, electrical conductivity, proline and diastase, and moderately negative values of specific rotation. Some samples from Spain and France showed a sucrose content higher than $5 \mathrm{~g} / 100 \mathrm{~g}$, but this seems to be more a sporadic exception than a typical feature of the honey. This honey type can be included in the

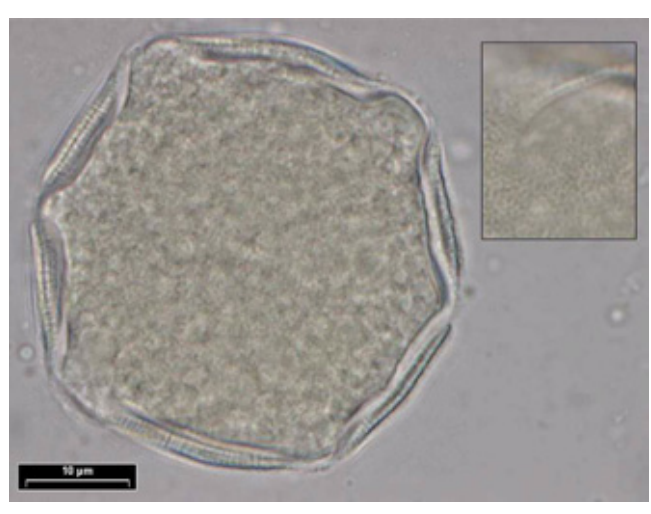

category of honeys with low enzyme content, for which the European Directive allows a minimum diastase number of 3 .

\begin{tabular}{|c|c|c|}
\hline \multicolumn{3}{|c|}{ Sensory description } \\
\hline \multirow[t]{2}{*}{ Visual assessment } & \multicolumn{2}{|c|}{ Colour intensity: very light } \\
\hline & \multicolumn{2}{|c|}{ Colour tone: normal honey colour } \\
\hline \multirow[t]{2}{*}{ Olfactory assessment } & \multicolumn{2}{|c|}{ Intensity of odour: weak to medium } \\
\hline & \multicolumn{2}{|c|}{ Description: fresh, floral - fresh fruit and vegetal } \\
\hline \multirow[t]{5}{*}{ Tasting assessment } & Sweetness: medium & Acidity: weak \\
\hline & Bitterness: absent & Intensity of aroma: weak to medium \\
\hline & \multicolumn{2}{|c|}{ Description of aroma: fresh, floral - fresh fruit and vegetal } \\
\hline & \multicolumn{2}{|c|}{ Persistencelaftertaste: short } \\
\hline & \multicolumn{2}{|c|}{ Other mouth perceptions: - } \\
\hline Physical characteristics & \multicolumn{2}{|c|}{ Crystallisation rate: moderate } \\
\hline
\end{tabular}



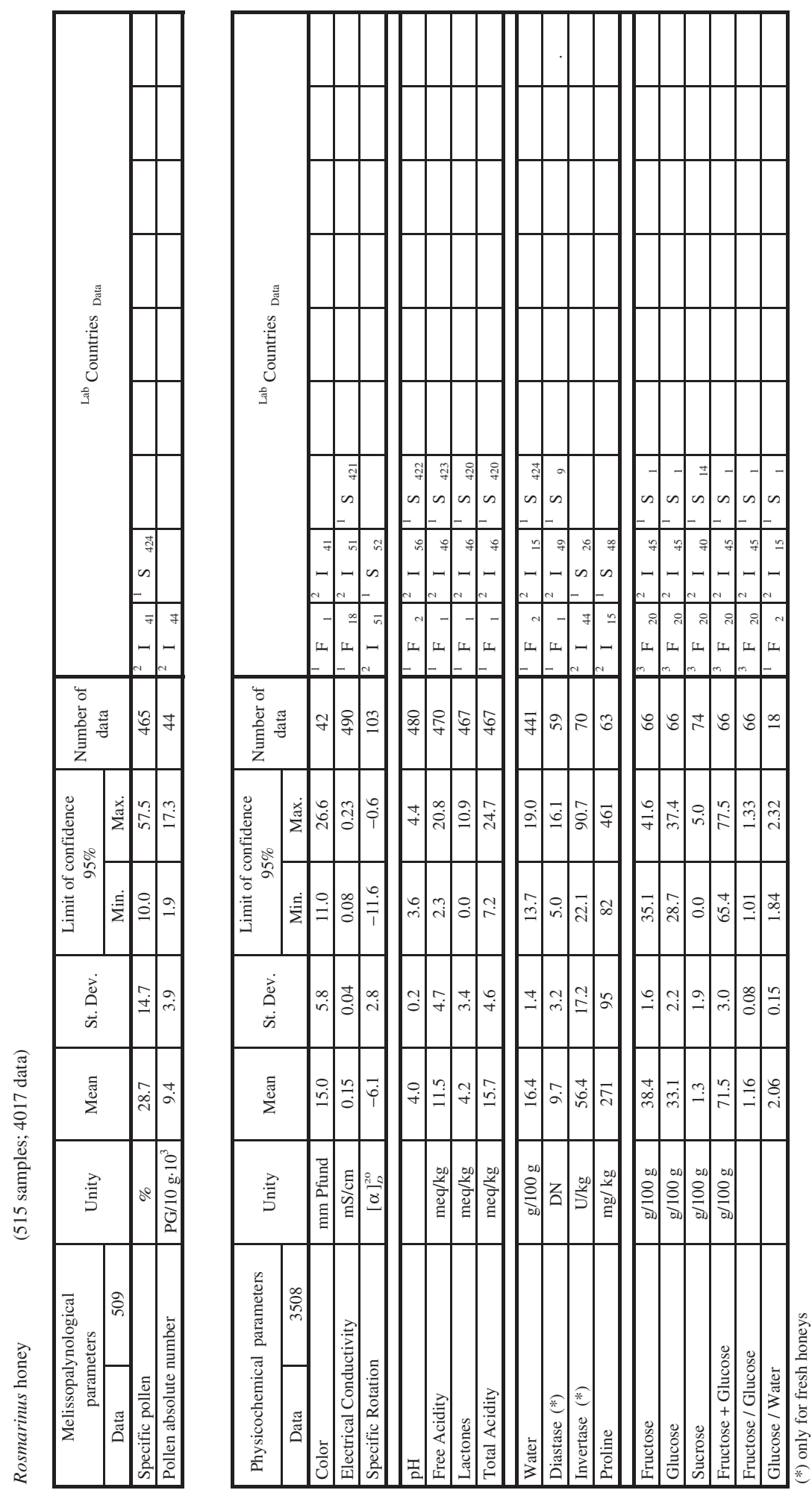


\section{DANDELION HONEY \\ (TARAXACUM OFFICINALE GROUP - ASTERACEAE)}

Taraxacum officinale is a polymorph botanical group widely spread in Europe, mainly in the Central countries. It represents one of the earlier nectar sources, not always exploited by the bee colonies, which are frequently not developed enough to gather it for honey production.

Dandelion unifloral honey has a typical yellow colour, quite a strong flavour and crystallises rapidly, due to the high glucose content. It is mostly sold in the production areas.

From the PG/10 g values (33 $600 \pm 15$ 100) the pollen of Taraxacum does not seem to be under-represented, however its percentage in the honey rarely goes beyond $50 \%$, and often it is lower than the associated species, such as Salix or Cruciferae. This could indicate that this honey type hardly ever is really pure, nevertheless the sensory and physicochemical patterns are very characteristic and the honey is easily recognisable.

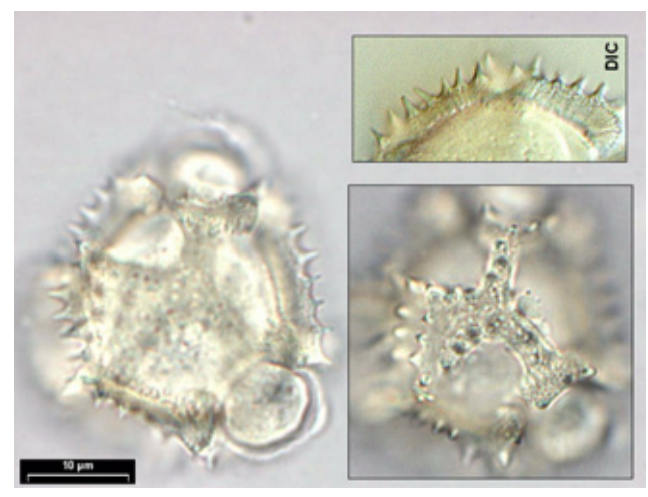

Taraxacum honey shows low values of acidity and F/G ratio, and high values of glucose, $\mathrm{F}+\mathrm{G}$ and $\mathrm{G} / \mathrm{W}$ ratio. In some Italian samples the diastase value was under the Directive limit of 8 .

\begin{tabular}{|c|c|c|}
\hline \multicolumn{3}{|c|}{ Sensory description } \\
\hline \multirow[t]{2}{*}{ Visual assessment } & \multicolumn{2}{|l|}{ Colour intensity: medium } \\
\hline & \multicolumn{2}{|l|}{ Colour tone: bright yellow } \\
\hline \multirow[t]{2}{*}{ Olfactory assessment } & \multicolumn{2}{|l|}{ Intensity of odour: strong } \\
\hline & \multicolumn{2}{|l|}{ Description: spoiled } \\
\hline \multirow[t]{5}{*}{ Tasting assessment } & Sweetness: medium & Acidity: medium \\
\hline & Bitterness: absent to weak & Intensity of aroma: strong \\
\hline & \multicolumn{2}{|c|}{ Description of aroma: woody and spoiled } \\
\hline & \multicolumn{2}{|l|}{ Persistencelaftertaste: long } \\
\hline & \multicolumn{2}{|c|}{$\begin{array}{l}\text { Other mouth perceptions: when crystallised with very small crystals, refreshing (like } \\
\text { "fondant") }\end{array}$} \\
\hline Physical characteristics & \multicolumn{2}{|c|}{$\begin{array}{l}\text { Crystallisation rate: quick } \\
\text { Other: this honey is often found in a crystallised form with very small crystals; in this } \\
\text { case the colour appears faint yellow (like custard) }\end{array}$} \\
\hline
\end{tabular}



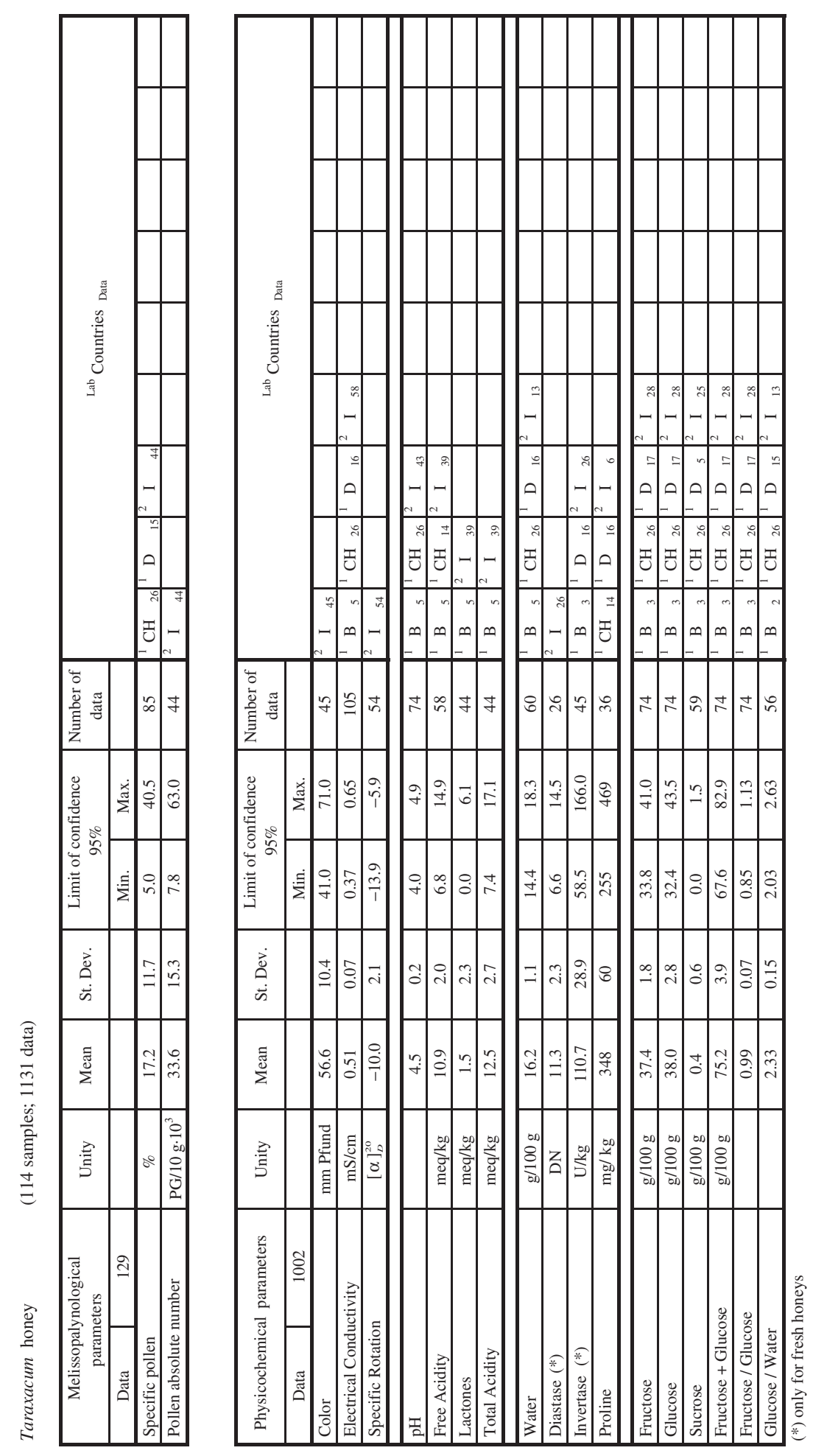


\section{THYME HONEY (THYMUS SPP. - LAMIACEAE)}

Different species of Thymus are found in the Mediterranean countries. Unifloral Thymus honey is produced in Italy mainly from $T h$. capitatus, in Greece from a variety of different species of Thymus and other Labiatae, and in Spain and France mainly from Th. vulgaris L. The data reported in this sheet are in large part from Italy and Greece. Other possible unifloral honeys from other Thymus species, with different characteristics, are not described here.

The melissopalynological pattern of Italian samples is more typical of a under-represented honey (PG/10 g: $10100 \pm 6$ 000; Thymus pollen $26.6 \% \pm 10.0$ ), while Greek samples show a very variable pollen content (PG/10 g: $33800 \pm 16700 ;$ Thymus pollen $40.2 \% \pm$ 16.4).

Unifloral thyme honey presents quite high values of diastase, high values of proline, fruc-

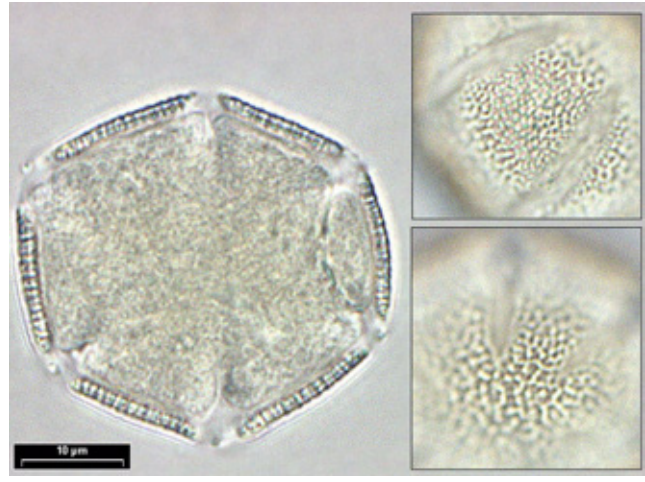

tose and acidity (causing a quick increase in HMF); the specific rotation has the lowest values.

\begin{tabular}{|c|c|c|}
\hline \multicolumn{3}{|c|}{ Sensory description (referred to honey from Thymus capitatus) } \\
\hline \multirow[t]{2}{*}{ Visual assessment } & \multicolumn{2}{|c|}{ Colour intensity: medium to dark } \\
\hline & \multicolumn{2}{|c|}{ Colour tone: normal honey colour } \\
\hline \multirow[t]{2}{*}{ Olfactory assessment } & \multicolumn{2}{|c|}{ Intensity of odour: medium } \\
\hline & \multicolumn{2}{|c|}{ Description: woody, chemical, fresh and floral - fresh fruit (floral) } \\
\hline \multirow[t]{5}{*}{ Tasting assessment } & Sweetness: medium & Acidity: medium \\
\hline & Bitterness: absent & Intensity of aroma: medium to strong \\
\hline & \multicolumn{2}{|c|}{ Description of aroma: woody, chemical, fresh and floral - fresh fruit } \\
\hline & \multicolumn{2}{|c|}{ Persistencelaftertaste: medium } \\
\hline & \multicolumn{2}{|c|}{ Other mouth perceptions: - } \\
\hline Physical characteristics & \multicolumn{2}{|c|}{ Crystallisation rate: moderate } \\
\hline
\end{tabular}




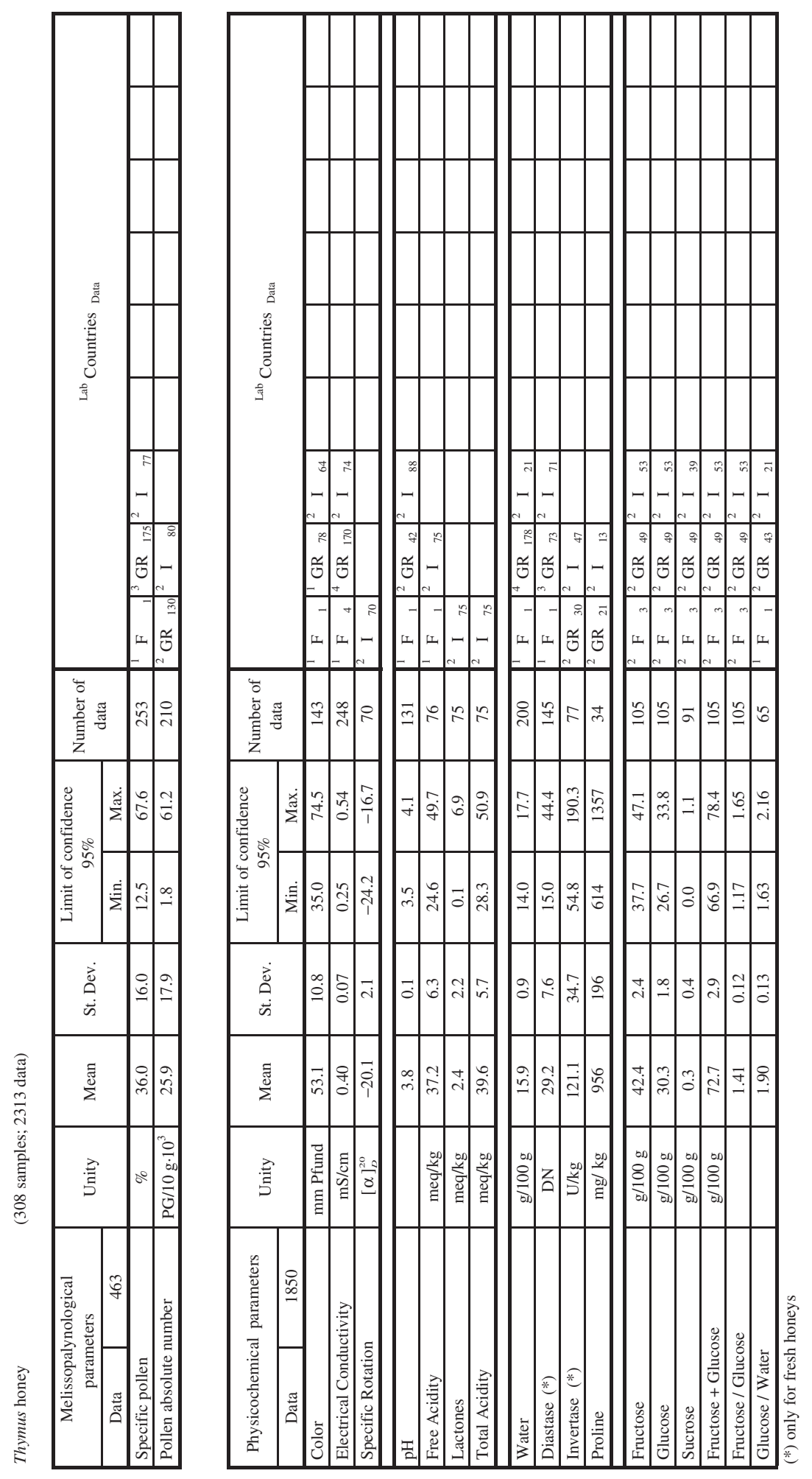




\section{LIME HONEY (TILIA SPP - TILIACEAE)}

Some species of Tilia (mainly T. platyphyllos and T. cordata) grow naturally in many European countries, and a number of different species, hybrids and varieties are cultivated as ornamental trees. All of them are very good sources of nectar, but can also provide honeydew, following the attack of some insects belonging to Rhynchota Homoptera, such as Eucallipterus tiliae L. (Callaphididae).

Unifloral honey is produced mainly in Central and Eastern European Countries. Outside Europe large amounts of Lime honey are produced in Russia and China. It has a good commercial value. It is not possible to distinguish between honeys from the different Tilia species, so one overall class is described here, referred to as Tilia spp.

Tilia pollen is under-represented, sometimes extremely (due to cultivated sterile varieties). Unifloral Tilia honey has average values for most of the physicochemical parameters. Electrical conductivity values are quite high, for a nectar honey, and the European Directive includes this honey in a group whose electrical conductivity may go beyond the $0.8 \mathrm{mS} / \mathrm{cm}$ limit. Several samples showed a sucrose content higher than $5 \mathrm{~g} / 100 \mathrm{~g}$, however this honey is not included among the ones for which a

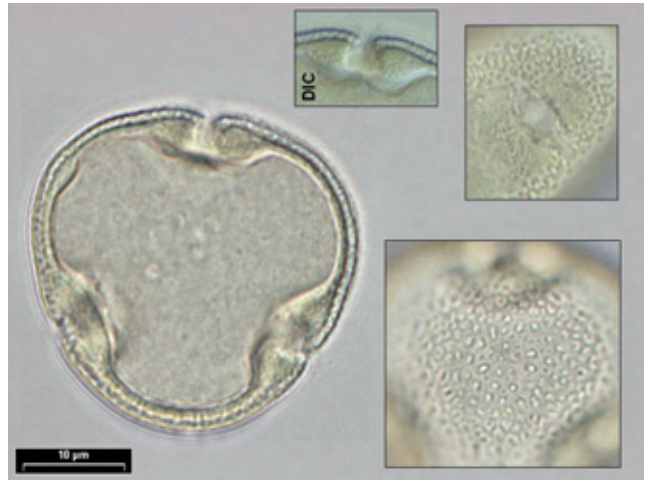

$10 \mathrm{~g} / 100 \mathrm{~g}$ limit is allowed by the European Directive. Some G+F values are lower than $60 \mathrm{~g} / 100 \mathrm{~g}$, but this can be accounted for by the possible presence of honeydew, which can also cause a certain variability in the other characteristics of lime honey (including colour, which is very light in pure nectar honey). This variability could also be caused by the fact that, due to the very strong and typical flavour of this honey, honeys not completely pure may be interpreted as unifloral.

\begin{tabular}{|c|c|c|}
\hline \multicolumn{3}{|c|}{ Sensory description } \\
\hline \multirow[t]{2}{*}{ Visual assessment } & \multicolumn{2}{|c|}{ Colour intensity: light to medium } \\
\hline & \multicolumn{2}{|c|}{ Colour tone: normal honey colour, with bright tone (yellow) } \\
\hline \multirow[t]{2}{*}{ Olfactory assessment } & \multicolumn{2}{|l|}{ Intensity of odour: strong } \\
\hline & \multicolumn{2}{|c|}{ Description: woody, chemical and fresh } \\
\hline \multirow[t]{5}{*}{ Tasting assessment } & Sweetness: medium & Acidity: weak \\
\hline & Bitterness: absent to medium & Intensity of aroma: strong \\
\hline & \multicolumn{2}{|c|}{ Description of aroma: woody, chemical and fresh } \\
\hline & \multicolumn{2}{|l|}{ Persistencelaftertaste: long } \\
\hline & \multicolumn{2}{|c|}{ Other mouth perceptions: astringent } \\
\hline Physical characteristics & \multicolumn{2}{|l|}{ Crystallisation rate: moderate } \\
\hline
\end{tabular}



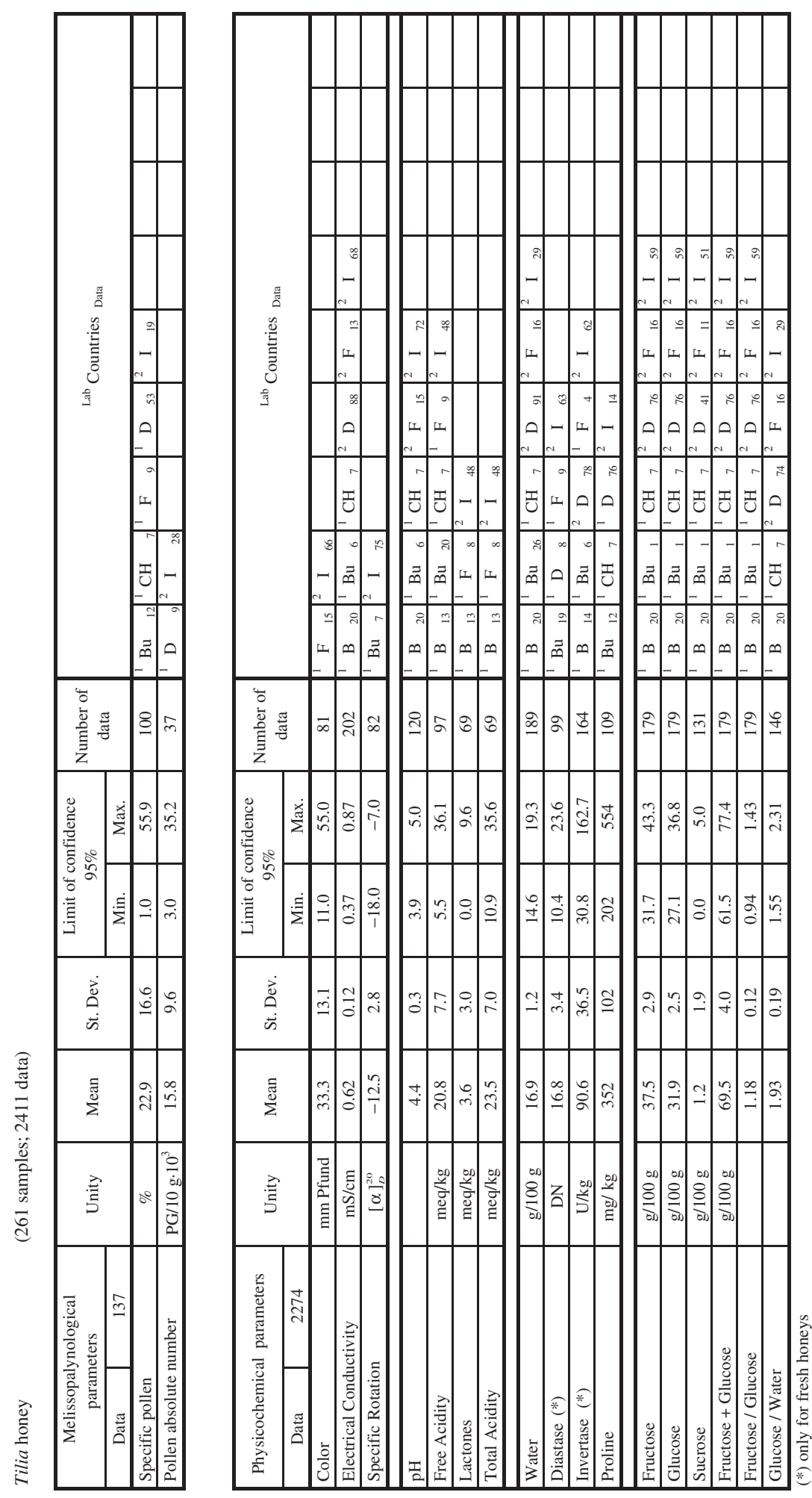


\section{HONEYDEW HONEY}

Honeydew can be produced by a wide variety of sucking insects on a number of different Coniferae, as Abies alba L. (Central and Northern Europe), A. cephalonica Loudon (Greece), Picea excelsa (Lam) Link. (Central and Northern Europe), Pinus halepensis Miller and $P$. brutia Ten. (Greece), and Latifoliae (produced in most of Europe, mainly from different Quercus species). The main physicochemical parameters of the respective honeys show quite homogeneous values, except for honey from honeydew produced by Metcalfa pruinosa (Say), that presents some different characteristics. Therefore only this type was kept separate, whereas all the other types are grouped in one global class of "honeydew honeys". However, it must be underlined that organoleptic characteristics and market value of these different types can vary.

Under microscopic examination honeydew honeys are characterised by the presence of numerous honeydew elements (HDE, such as mold hyphae and spores, unicellular algae), and pollen from nectarless plants. In the IHC data set, the HDE/pollen ratio was often found below

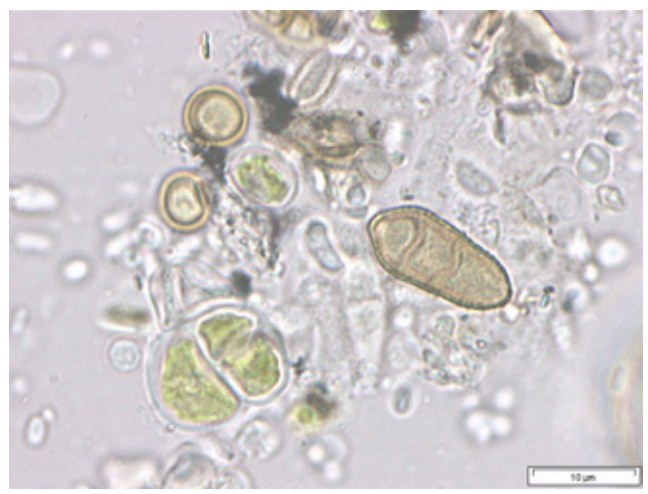

the limit of 3 that, according to Louveaux et al. (1978), should be typical of this honey.

The physicochemical pattern of honeydew honey includes high values for colour, electrical conductivity and $\mathrm{pH}$, positive values of specific rotation and low values of fructose, glucose, F+G and G/W. For honeydew honey, the European Directive requires a value of electrical conductivity higher than $0.8 \mathrm{mS} / \mathrm{cm}$ and allows a minimum $\mathrm{F}+\mathrm{G}$ of $45 \mathrm{~g} / 100 \mathrm{~g}$.

\begin{tabular}{|c|c|c|}
\hline \multicolumn{3}{|c|}{ Sensory description (referred to honey from Abies alba honeydew ) } \\
\hline \multirow[t]{2}{*}{ Visual assessment } & \multicolumn{2}{|c|}{ Colour intensity: dark to very dark } \\
\hline & \multicolumn{2}{|c|}{ Colour tone: normal honey colour with green fluorescence } \\
\hline \multirow[t]{2}{*}{ Olfactory assessment } & \multicolumn{2}{|c|}{ Intensity of odour: medium } \\
\hline & \multicolumn{2}{|c|}{ Description: woody and warm } \\
\hline \multirow[t]{5}{*}{ Tasting assessment } & Sweetness: medium & Acidity: weak \\
\hline & Bitterness: absent & Intensity of aroma: medium \\
\hline & \multicolumn{2}{|c|}{ Description of aroma: woody and warm } \\
\hline & \multicolumn{2}{|c|}{ Persistence/aftertaste: medium } \\
\hline & \multicolumn{2}{|c|}{ Other mouth perceptions: sometimes astringent } \\
\hline Physical characteristics & \multicolumn{2}{|c|}{$\begin{array}{l}\text { Crystallisation rate: slow } \\
\text { Other: it is very commonly of a very thick consistency, due to a low water content }\end{array}$} \\
\hline
\end{tabular}




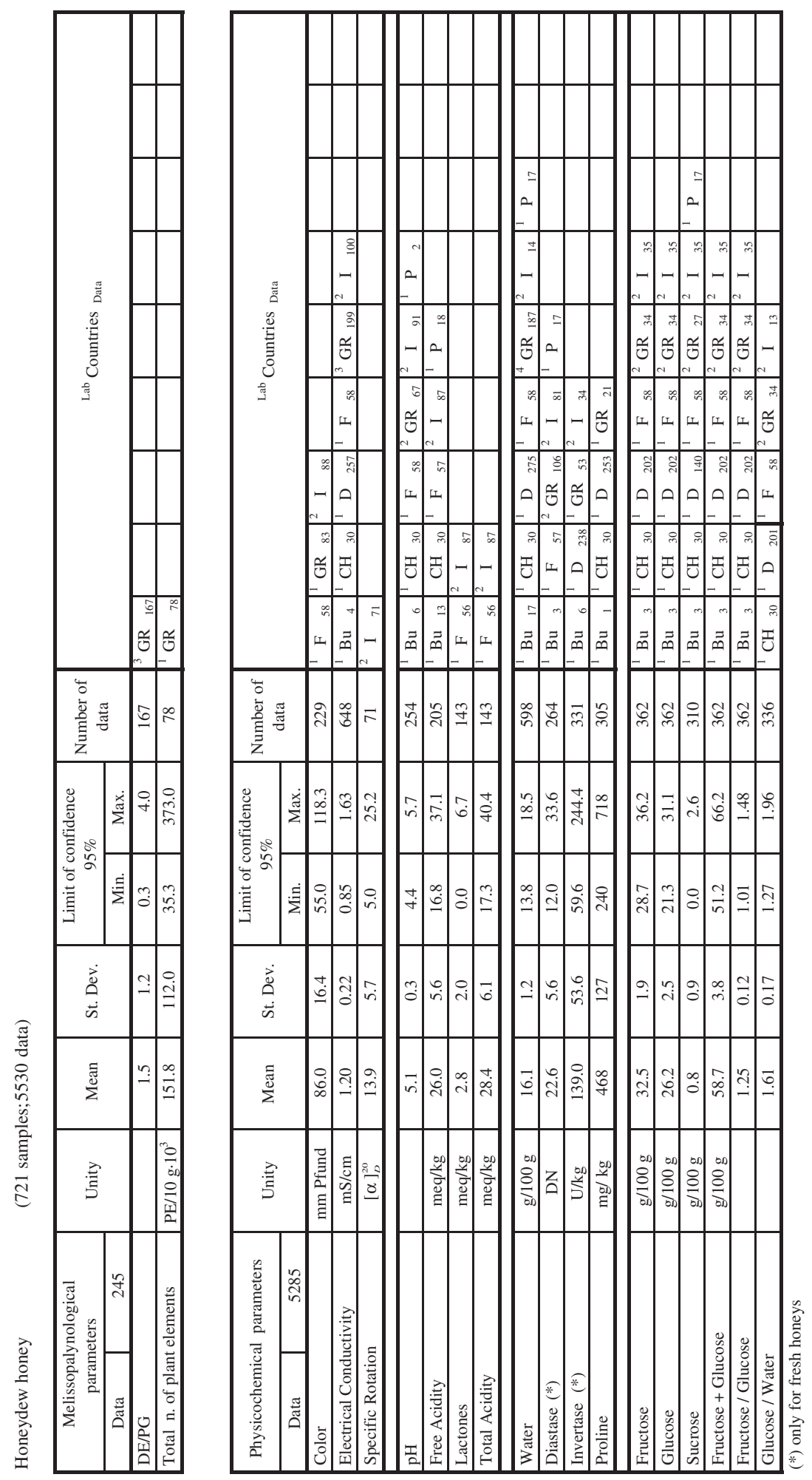




\section{METCALFA HONEYDEW HONEY (METCALFA PRUINOSA (SAY) RINCHOTA HOMOPTERA, FLATIDAE)}

Metcalfa pruinosa is an insect introduced in Europe at the end of the 1970s and now spread to Italy, Slovenia and France, where it attacks many indigenous and cultivated species, giving rise, in summer, to significant quantities of unifloral honey. On the market this honey is usually sold with the generic denomination of honeydew honey.

Under microscopic examination Metcalfa honeydew honeys are characterised by the presence of numerous honeydew elements (mold hyphae and spores, unicellular algae), and pollen from nectarless plants. The ratio $\mathrm{HDE} /$ pollen is mostly higher than 3. Metcalfa honeydew honey shows a very characteristic pattern, with high values of colour, electrical conductivity, diastase, invertase, $\mathrm{pH}$ and acidity (even beyond the $50 \mathrm{meq} / \mathrm{kg}$ limit prescribed by the European Directive), positive values of specific rotation and low values of fructose, glucose, F+G and G/W. For honeydew honeys, the European Directive requires a value of elec-

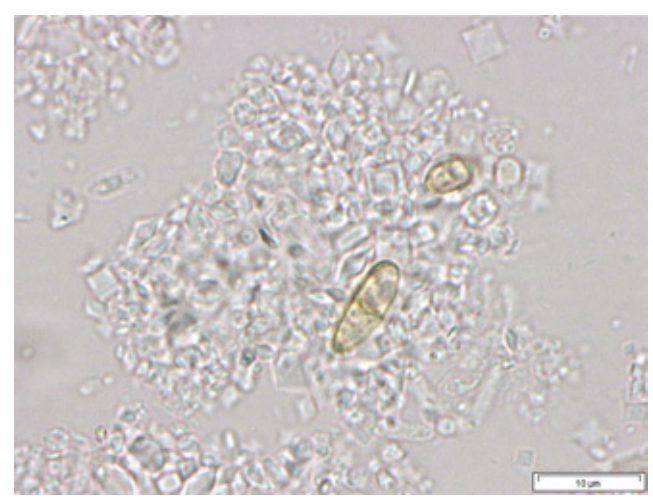

trical conductivity higher than $0.8 \mathrm{mS} / \mathrm{cm}$ and allows a minimum $\mathrm{F}+\mathrm{G}$ content of $45 \mathrm{~g} / 100 \mathrm{~g}$. The sugar spectrum of this honey type also includes a high dextrin content (Fiori et al., 2000).

\begin{tabular}{|c|c|c|}
\hline \multicolumn{3}{|c|}{ Sensory description } \\
\hline \multirow[t]{2}{*}{ Visual assessment } & \multicolumn{2}{|c|}{ Colour intensity: very dark } \\
\hline & \multicolumn{2}{|c|}{ Colour tone: normal honey colour } \\
\hline \multirow[t]{2}{*}{ Olfactory assessment } & \multicolumn{2}{|c|}{ Intensity of odour: medium } \\
\hline & \multicolumn{2}{|c|}{ Description: woody, floral - fresh fruit (fruity), warm and vegetal } \\
\hline \multirow[t]{5}{*}{ Tasting assessment } & Sweetness: medium & Acidity: weak \\
\hline & Bitterness: absent & Intensity of aroma: medium \\
\hline & \multicolumn{2}{|c|}{ Description of aroma: woody, floral - fresh fruit (fruity), warm and vegetal } \\
\hline & \multicolumn{2}{|c|}{ Persistencelaftertaste: medium } \\
\hline & \multicolumn{2}{|c|}{ Other mouth perceptions: sometimes astringent } \\
\hline Physical characteristics & \multicolumn{2}{|c|}{$\begin{array}{l}\text { Crystallisation rate: slow } \\
\text { Other: it is very commonly of a very thick consistency, due to a low water content }\end{array}$} \\
\hline
\end{tabular}



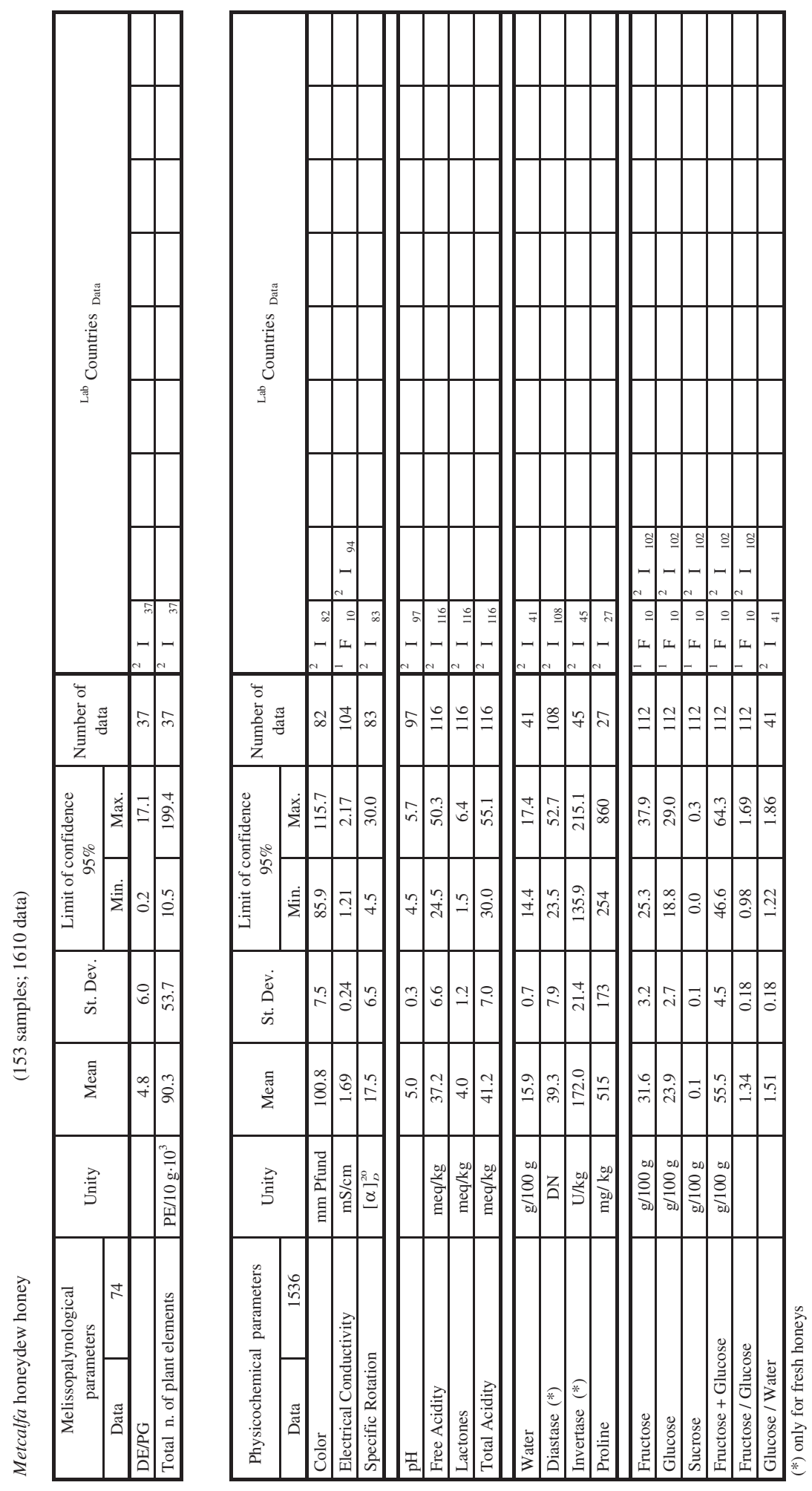